\title{
The use of simultaneous chemical precipitation in modified activated sludge systems exhibiting biological excess phosphate removal Part 7: Application of the IAWQ model
}

\author{
DW de Haas", MC Wentzel* and GA Ekama \\ Dept. of Civil Engineering, University of Cape Town, Rondebosch 7701, South Africa
}

\begin{abstract}
The IAWQ Activated Sludge Model (ASM) No. 2 is a kinetic-based model and incorporates two simple processes for chemical precipitation and redissolution that are readily integrated with biological processes for carbon, nitrogen and phosphorus removal. This model was applied to experimental data collected as part of this study from parallel pilot-scale 3 -stage Phoredox systems with and without simultaneous dosing of chemical precipitant. The precipitants tested were alum, ferric chloride and ferrous-ferric chloride. The model was calibrated to the control unit (without precipitant addition) in order to match effluent phosphate (P) predictions (and hence P removal) as closely as possible. The same calibration was then applied to modelling the test unit (with precipitant addition). It was found that the default model input stoichiometry for the precipitation reaction (ideal 1:1 molar ratio of metal ion (Me) to P) was suitable for ferric chloride addition at a $20 \mathrm{~d}$ sludge age, but did not accurately reflect the test system behaviour for all experimental periods. A lower stoichiometry ( 0.60 to 0.75$)$ was required for alum at a $20 \mathrm{~d}$ sludge age, and for a blend of predominantly ferrous chloride at a $10 \mathrm{~d}$ sludge age. The input stoichiometry was further decreased under P-limiting conditions. A simple approach to, and possible reasons for, the manipulation of the model stoichiometry are discussed in the light of observed stoichiometry from system P removal and fractionation data collected as part of this study. Furthermore, an alternative approach based on manipulation of the precipitation (and hence redissolution) kinetic constant is suggested and evaluated using available experimental data. Model predictions and observed data in respect of polyphosphate (polyP) and suspended solids are also compared and discussed. It is concluded that the ASM No. 2 model provides a useful basis for modelling simultaneous $\mathrm{P}$ precipitation, provided certain minor modifications are made. Further investigation into the kinetics of the precipitation process(es) is recommended, particularly in relation to the effect of system sludge age. The model lends itself to further enhancement by incorporating additional physico-chemical processes.
\end{abstract}

\section{Nomenclature}

D Delta, meaning "difference in" or "change in" (e.g. $\left.\mathrm{DP}_{\text {trem }}\right)$

$\mathrm{m}_{\text {AUT }} \quad$ Maximum specific growth rate of the autotrophs (nitrifiers), $\mathrm{d}^{-1}$

AE1 or 2 Aerobic zone or reactor $\left(1^{\text {st }}\right.$ or $\left.2^{\text {nd }}\right)$

BEPR Biological excess P removal

COD Chemical oxygen demand

$\mathrm{C}_{\mathrm{TKN}}$ or Nti Influent TKN concentration

$\mathrm{C}_{\mathrm{TP}}$ or $\mathrm{P}_{\mathrm{ti}}$ Influent total $\mathrm{P}$ concentration

$\mathrm{f}_{\mathrm{ac}} \quad$ Fraction of RBCOD which is acetate (i.e. $\mathrm{S}_{\mathrm{A}} /\left(\mathrm{S}_{\mathrm{A}}+\mathrm{S}_{\mathrm{F}}\right)$

$\mathrm{f}_{\mathrm{bs}} \quad$ Fraction of (influent) biodegradable COD which is readily biodegradable

$\mathrm{f}_{\text {up }} \quad$ Fraction of (influent) total COD which is unbiodegradable particulate $\operatorname{COD}\left(\mathrm{X}_{\mathrm{I}}\right)$

$\mathrm{f}_{\text {us }} \quad$ Fraction of (influent) total COD which is unbiodegradable soluble COD $\left(\mathrm{S}_{\mathrm{T}}\right)$

IAWQ International Association on Water Quality (now International Water Association, IWA)

$\mathrm{I}_{\mathrm{NSI}} \quad \mathrm{N}$ content of unbiodegradable soluble $\mathrm{COD}\left(\mathrm{S}_{\mathrm{I}}\right)$

ISS Inorganic suspended solids

$\mathrm{k}_{\mathrm{PRE}} \quad$ Kinetic (rate) constant for precipitation in IAWQ model

$\mathrm{k}_{\mathrm{DIS}}$ Kinetic (rate) constant for redissolution in IAWQ model

\# Formerly Umgeni Water, PO Box 9, Pietermaritzburg 3200.

* To whom all correspondence should be addressed.

푱(021) 650-2583; fax (021) 689-7471; e-mail: markw@eng.uct.ac.za

Received 14 November 2000.

\begin{tabular}{|c|c|}
\hline $\mathrm{Me}$ & General symbol for metal trivalent ions \\
\hline $\mathrm{MeOH}$ & Metal hydroxide e.g. $\mathrm{Fe}(\mathrm{OH})_{3}$ \\
\hline $\mathrm{MeP}$ & $\begin{array}{l}\text { Metal phosphate or metal hydroxy phosphate (depends } \\
\text { on stoichiometry) }\end{array}$ \\
\hline orthoP & Orthophosphate \\
\hline $\mathrm{O}_{\mathrm{t}}$ & Oxygen uptake rate (in $\mathrm{mg} /[\ell \cdot \mathrm{h}])$ \\
\hline $\mathrm{P}$ & Phosphate \\
\hline PHA & $\begin{array}{l}\text { Polyhydroxy-alkanoate (organic storage products of } \\
\text { PAOs) }\end{array}$ \\
\hline polyP & Polyphosphate \\
\hline $\mathrm{P}_{\text {tret }}$ & Total $\mathrm{P}$ concentration removed \\
\hline $\mathrm{RBCOD}$ & Readily biodegradable soluble COD in the influent \\
\hline rem & Removal/removed \\
\hline $\mathrm{S}_{\mathrm{A}}$ & $\begin{array}{l}\text { Fermentation products as acetate concentration } \\
\text { (together with } S_{\mathrm{F}} \text { makes up the RBCOD) }\end{array}$ \\
\hline SD & Sample standard deviation \\
\hline$S_{\mathrm{F}}$ & $\begin{array}{l}\text { Fermentable substrate concentration (RBCOD which } \\
\text { can be converted to acetate) }\end{array}$ \\
\hline $\mathrm{S}_{\mathrm{I}}$ & Soluble unbiodegradable COD concentration \\
\hline $\mathrm{S}_{\mathrm{NH} 4}$ & Soluble ammonia concentration \\
\hline $\mathrm{S}_{\mathrm{NO} 3}$ & Soluble nitrate concentration \\
\hline $\mathrm{S}_{\mathrm{PO} 4}$ & Soluble orthoP concentration \\
\hline $\mathrm{S}_{\mathrm{TCOD}}^{\mathrm{PO}}$ or $\mathrm{S}_{\mathrm{ti}}$ & Influent (total) COD concentration \\
\hline $\mathrm{S}_{\mathrm{TKN}}$ & Soluble TKN concentration \\
\hline TKN & Total Kjeldahl nitrogen \\
\hline Total P & Total phosphate concentration \\
\hline TSS & Total suspended solids \\
\hline VSS & Volatile suspended solids \\
\hline WWW & Wastewater works \\
\hline
\end{tabular}


$\mathrm{X} \quad$ General symbol for solids (e.g. $\mathrm{X}_{\mathrm{vss}}$ in IAWQ model)

$\mathrm{X}_{\mathrm{A}} \quad$ Autotrophic (nitrifier) biomass concentration

$\mathrm{X}_{\mathrm{H}} \quad$ Heterotrophic (non PAO) biomass concentration

$\mathrm{X}_{\mathrm{I}}$ Unbiodegradable, particulate organics concentration (COD)

$\mathrm{X}_{\mathrm{MeOH}}$ Solids concentration as metal hydroxide

$\mathrm{X}_{\mathrm{MeP}}$ Solids concentration as metal (hydroxy) phosphate

$\mathrm{X}_{\mathrm{PAO}}$ Heterotrophic phosphorus accumulating organism (PAO) biomass concentration

$\mathrm{X}_{\mathrm{PP}}\left(\right.$ or $\left.\mathrm{P}_{\mathrm{pp}}\right)$ PolyP as model parameter in IAWQ (or UCTPHO) model

$\mathrm{X}_{\mathrm{S}} \quad$ Slowly biodegradable substrate concentration (COD)

$\mathrm{Y}_{\mathrm{PO} 4} \quad$ Yield stoichiometric constant of $\mathrm{S}_{\mathrm{PO} 4}$ release (polyP requirement) for PHA storage

\section{Introduction}

The first five parts of this series of papers (De Haas et al., 2000a to d; 2001a) outlined the background and experimental investigation conducted into simultaneous chemical precipitation of phosphate in a biological nutrient removal (BNR) modified activated sludge systems, at pilot scale. In Part 6 (De Haas et al., 2001b), existing models for the chemical precipitation phenomenon were reviewed. It was concluded from Part 6 that the approach followed for the precipitation processes in the IAWQ Activated Sludge Model (ASM) No. 2 (Henze et al., 1995) has the advantage of being relatively simple and can be most readily incorporated into an existing kinetic model for the biological processes. Accordingly, an investigation was carried out in which the ASM No. 2 was applied to the experimental results reported in Parts 3, 4 and 5 (De Haas et al., 2000c; d; 2001a). This paper describes the outcome of that investigation with the aim of evaluating the predictive power of ASM No.2 for BNR-activated sludge systems incorporating simultaneous addition of aluminium or iron salts for supplementary phosphorus removal.

\section{Modelling method}

The IAWQ ASM No.2 (ASM2) model was available in matrix format (Henze et al., 1995). To apply this model as a computer program, it was formulated using the AQUASIM platform (Reichert, 1994), based on the three-stage Phoredox configuration used in the pilot plant trials for this investigation (De Haas et al., 2000c). With the exception of the maximum specific growth rate of the nitrifiers $\left(\mathrm{m}_{\mathrm{AUT}}\right)$, which is considered to be part of influent characteristisation, the default values applied for kinetic and stoichiometric constants in the ASM2 model were those proposed by Wentzel and Ekama (1995).

To verify that ASM2 had been correctly set up in AQUASIM, the performance of the control unit (R2) for all experimental periods was simulated and the results compared to those obtained using the UCTPHO model described by Wentzel et al. (1992) and made available as a computer program by Wentzel (1997). Making allowance for the difference in approach to influent characteristics in the two models by ensuring both models had the same concentrations for the various influent fractions, satisfactory agreement between the IAWQ and UCTPHO models was achieved (De Haas, 1998).

\section{Influent characterisation}

In order to apply the ASM2 model, the concentrations of the various influent COD fractions need to be input (see below). Then, apart from influent ammonia (which must be specified), the influent nitrogen fractions are calculated in proportion to the COD fractions. A similar procedure applies for influent phosphorus fractions. Further, since $m_{\text {AUT }}$ can vary significantly, it was also considered to be an "influent characteristic" and adjusted to match effluent ammonia concentrations on the basis of experimental data.

\section{Readily biodegradable COD}

A shortcoming of the experimental procedure followed for the operation of the pilot plants (De Haas et al., 2000c) was that the influent readily biodegradable COD (RBCOD) fraction was not specifically measured throughout. The initial intention was to develop fully "enhanced" cultures in the pilot plants such that the influent COD was composed of $100 \%$ sodium acetate (i.e. $100 \%$ RBCOD). However, the settling problems that emerged in the test unit (alum dosed) and later also in the control unit during the first alum dosing period with $250 \mathrm{mg} / \mathrm{l}$ acetate COD (see Part 3, De Haas et al., 2000c) resulted in a revision of the experimental approach. A lower acetate supplement in the influent (usually 150 $\mathrm{mg} / \ell$ as COD) was accepted (De Haas et al., 2000c to d; 2001a), with the settled sewage contributing the balance of the influent COD. This resulted in the influent composition being more variable than would ideally have been preferred.

For a limited number of experimental periods (Periods 3.6.1 and 3.6.2a,b with ferric chloride dosing - see De Haas et al., 2000d), RBCOD was measured using the physico-chemical method of Mamais et al. (1993). For these periods, the measured RBCOD values were used for characterisation of the influent. For the remainder of the experimental periods, the absence of RBCOD data necessitated a trial-and-error approach with respect to characterisation of the influent COD fractions. This was accomplished using the IAWQ ASM2 model by calibrating against the experimental results for the control unit (R2), as described below. Since the principal aim of the investigation was to evaluate the chemical precipitation processes in IAWQ ASM2, this approach was not unacceptable.

\section{COD fractions}

The IAWQ ASM2 model has seven influent COD fractions: "acetate" (or other similar fermentation products, considered to be RBCOD) $\left(\mathrm{S}_{\mathrm{A}}\right.$ ); fermentable substrate (also RBCOD) $\left(\mathrm{S}_{\mathrm{F}}\right.$ ); soluble unbiodegradable COD $\left(\mathrm{S}_{\mathrm{I}}\right)$; particulate unbiodegradable COD $\left(\mathrm{X}_{\mathrm{I}}\right)$; slowly biodegradable substrate $\left(\mathrm{X}_{\mathrm{S}}\right)$; autotrophic biomass $\left(\mathrm{X}_{\mathrm{A}}\right)$; heterotrophic organisms $\left(\mathrm{X}_{\mathrm{H}}\right)$ and PAO biomass $\left(\mathrm{X}_{\mathrm{PAO}}\right)$. Unless the influent sewage has been aerated at some point, influent biomasses $\mathrm{X}_{\mathrm{H}}, \mathrm{X}_{\mathrm{A}}$ and $\mathrm{X}_{\mathrm{PAO}}$ may be taken as zero (Wentzel and Ekama, 1995). For each experimental period modelled, by means of a trial-and-error procedure, the influent characterisitics which gave the best fit of modelled to experimental data were derived, starting with the control unit (R2) which was not dosed with metal salts. The following steps were followed in this procedure:

- $\mathrm{m}_{\mathrm{AUT}(20)}$ : Adjusted such that predicted effluent ammonia concentration matched observed ammonia (free and saline) values;

- $\mathrm{I}_{\mathrm{NSI}}$ : Varied such that predicted effluent TKN matched observed values, taking into account that residuals of ammonia and organic biodegradable $\mathrm{N}$ also contribute to the effluent TKN.

- $\mathrm{S}_{\mathrm{I}}$ : Varied such that predicted effluent total COD matched observed values. [This approach is consistent with allowing for a theoretical COD mass balance for the system. The model set- 
up assumed that the effluent contains zero effluent suspended solids. This is not achievable in practice, with the effluent containing an estimate of $\sim 10$ to $25 \mathrm{mg} / \mathrm{l}$ suspended solids. In the approach followed here, the COD contribution from the solids is lumped with soluble unbiodegradable effluent COD, $\left.S_{I}\right]$.

- Influent $\mathrm{S}_{\mathrm{A}}$ : Fixed by the known acetate dose in most cases. [The only exceptions were experimental periods 3.4.1 to 3.4.4 (inclusive) where observed $P$ removal in the control unit was significantly less than that predicted by either the UCTPHO or IAWQ models. This point is discussed later. For these periods, a lower $S_{A}$ value was accepted].

- Influent $S_{\mathrm{F}}, \mathrm{X}_{\mathrm{I}}$ and $\mathrm{S}_{\mathrm{NH} 4}$ : Adjusted in a series of iterations to match the following:

- Predicted VSS concentrations in the second (last) aerobic reactor to within approximately $\pm 10 \%$ of the observed values.

- Influent $S_{\mathrm{F}}$ concentrations to available RBCOD data (for Periods 3.6.1 and 3.6.2) as a guide, and assuming that the $\mathrm{S}_{\mathrm{A}}$ concentrations in the source sewage were negligible before supplementation.

- Predicted effluent (i.e. filtered second aerobic reactor) nitrate concentrations to within $\leq 1 \mathrm{mg} / \ell$ of the observed values [This approach ensured that nitrate recycled to the anaerobic reactor was matched in the model as closely as possible to that observed in the experimental system. The key objective in this study was to model biological excess $P$ removal (BEPR) in the control unit as a basis for comparing it to the behaviour of the test unit with metal salt addition. To this extent, $N$ removal processes and the adjustment to influent ammonia (and hence TKN) were considered to be of secondary importance in this study].

- Predicted effluent $\mathrm{S}_{\mathrm{PO} 4}$ (orthoP) concentrations to measured effluent total P concentrations [Since the model did not make allowance for effluent suspended solids, a match of model effluent orthoP to measured total $P$ was valid on a mass balance basis. The predicted and measured P removal could therefore be compared].

\section{Stoichiometry of $\mathrm{P}$ release and PHA storage $\left(\mathrm{Y}_{\mathrm{PO} 4}\right)$}

During initial modelling attempts, UCTPHO results for the control unit (R2) were compared to those for the IAWQ model. It was found that the reactor soluble orthoP concentrations $\left(\mathrm{P}_{\mathrm{s}}\right.$ or $\left.\mathrm{S}_{\mathrm{PO} 4}\right)$ and polyP concentrations $\left(\mathrm{P}_{\mathrm{pp}}\right.$ or $\left.\mathrm{X}_{\mathrm{PP}}\right)$ predicted by the two models did not always agree well, despite similar predictions for other critical parameters (e.g. nitrate and polyhydroxy-alkanoate, PHA). The IAWQ model sometimes over-predicted biological P removal (i.e. gave lower reactor and effluent orthoP concentrations), while in a few cases it under-predicted biological P removal. It was concluded that the critical parameter in these comparisons was the stoichiometry of $\mathrm{P}$ release during sequestration of acetate (i.e. storage of PHA) as defined by the yield constant $\mathrm{Y}_{\mathrm{PO} 4}$. Henze et al. (1995) suggested a value of $\mathrm{Y}_{\mathrm{PO} 4}=0.40 \mathrm{mgP} / \mathrm{mgCOD}$ for this constant, but Wentzel and Ekama (1995) recommended a higher value $\left(\mathrm{Y}_{\mathrm{PO} 4}=0.52 \mathrm{mgP} /\right.$ $\mathrm{mgCOD}$ ). An increase in $\mathrm{Y}_{\mathrm{PO} 4}$ produces more $\mathrm{P}$ release (i.e. poly $\mathrm{P}$ hydrolysis) per unit COD stored as PHA, and hence, with the same $\mathrm{P}$ uptake per unit COD as PHA utilised, a lower system $\mathrm{P}$ removal. By trial-and-error, fitting predicted to measured data for the experimental periods of this study, it appeared that adjustment of $\mathrm{Y}_{\mathrm{PO} 4}$ was required in the range 0.50 to $0.57 \mathrm{mgP} / \mathrm{mgCOD}$ (Table 1). Smolders et al. (1994) found that the stoichiometry of P release with the uptake of acetate (i.e. $\mathrm{Y}_{\mathrm{PO} 4}$ ) was a function of $\mathrm{pH}$ : $\mathrm{Y}_{\mathrm{PO} 4}$ increased with $\mathrm{pH}$, ranging from ca. $0.3 \mathrm{~mol} \mathrm{P} / \mathrm{mol} \mathrm{C}$ at $\mathrm{pH}$ 6, to ca. 0.75 at $\mathrm{pH}$ 8.3. At neutral $\mathrm{pH}$, Smolders et al. (1994) reported an average $\mathrm{Y}_{\mathrm{PO} 4}$ value of about $0.5 \mathrm{~mol} \mathrm{P} / \mathrm{mol} \mathrm{C}$. However, in the $\mathrm{pH}$ range 6.8 to 7.5 (typical anaerobic reactor $\mathrm{pH}$ range found in this study), the data scattered in the range ca. 0.42 to $0.6 \mathrm{~mol} \mathrm{P} / \mathrm{mol} \mathrm{C}$, which is equivalent to 0.41 to $0.58 \mathrm{mg} \mathrm{P} / \mathrm{mg}$ COD as acetic acid (Smolders et al., 1994). This suggested that the adjusted values for $\mathrm{Y}_{\mathrm{PO} 4}$ used here were in a valid range, although the effect of $\mathrm{pH}$ on this coefficient was not specifically determined.

\section{$\mathrm{pH}$ and alkalinity in the models}

The IAWQ model assumes that $\mathrm{pH}$ in the activated sludge system is maintained close to neutrality. This is an acceptable assumption given that most biological systems operate optimally at a $\mathrm{pH}$ close to neutral. In Parts 3, 4 \& 5 (De Haas et al., 2000c to d; 2001a), it was reported that the reactor $\mathrm{pH}$ in the pilot plant systems used here fluctuated in the range 6.9 to 7.8 , with median values close to $\mathrm{pH}$ 7.4. On this basis, the inherent assumption in the model with respect to $\mathrm{pH}$ appeared to be acceptable.

The IAWQ model does make provision for predicting changes in system alkalinity. This is particularly useful where low alkalinity influent wastewaters could yield a deficit in alkalinity as a result of nitrification or chemical precipitation reactions. The change in system alkalinity due to metal hydroxide $(\mathrm{MeOH})$ precipitation, followed by the reaction of $\mathrm{MeOH}$ to form metal (hydroxy) phosphate $(\mathrm{MeP})$ precipitate may be easily included on the basis of known (or assumed) stoichiometry for $\mathrm{MeOH}\left(\mathrm{e} . \mathrm{g} \mathrm{Me}(\mathrm{OH})_{3}\right.$ ) and $\mathrm{MeP}$ (e.g. $\mathrm{Me}_{\mathrm{r}} \mathrm{PO}_{4}(\mathrm{OH})_{3 \mathrm{r}-3}$ - see Stoichiometry of chemical precipitation in IAWQ model below). However, since surplus bicarbonate alkalinity (approx. 70 to $300 \mathrm{mg} / \ell$ as $\mathrm{CaCO}_{3}$ ) was always present in the effluent during the experimental periods considered here, alkalinity was not included as a model parameter in this investigation.

\section{Adopted influent characteristics and model calibration}

The adopted influent characteristics based on calibration of the IAWQ ASM2 model against the control unit (R2) are given in Table 1.

From Table 1, the following points may be highlighted:

- For Periods 3.6.1 and 3.6.2 ( $\mathrm{a} \& \mathrm{~b}$ ), which spanned a period of approximately 5 months in 1997, moving from dry weather in winter into wet weather in early summer, the RBCOD of the influent was measured using a physico-chemical method (Mamais et al., 1993). During these periods, the added acetate concentration was held constant at $100 \mathrm{mg} / \ell$ as COD. Based on the measured RBCOD during these periods and subtracting $100 \mathrm{mg} / \ell$ (known influent $\mathrm{S}_{\mathrm{A}}$ ), estimated values for $\mathrm{S}_{\mathrm{F}}$ were derived. The results obtained for Periods 3.6.1 and 3.6.2 (a \& b), taken as a whole, were $S_{F}=76( \pm 62)($ mean $\pm S D)$ and total $\mathrm{COD}=400( \pm 96)$. Table 1 shows that the mean value for $\mathrm{S}_{\mathrm{F}}$ adopted was $76( \pm 44)$ and the mean measured influent COD was $360( \pm 74)$ for all the experimental periods subjected to modelling here, which suggests satisfactory overall conformity between the measured and adopted values for $S_{F}$.

- Some periods required relatively high values for $f_{\text {up }}(0.11$ to 0.18 ) in order to match observed VSS values for the control unit (R2). These periods appeared to correspond to periods in which the catchment of Darvill WWW (sewage source) received significant rainfall, notably:

Period 3.3.4: October 1995 (spring-summer) 
Period 3.3.5: November 1995 (summer)

Period 3.3.6: November - December 1995 (summer)

Period 3.4.1: December 1995 - January 1996 (summer, accompanied by floods)

Period 3.5.1: Mid June - July 1996 (unusual winter rainfall, with widespread heavy rain and snow).

[The data for these periods therefore appear to confirm observations made in Parts 3, 4 and 5 (De Haas et al., 2000c to d; 2001a) that the Darvill settled sewage varied considerably in composition, and that this variation was partly due to the heavy ingress of rainwater, and/or groundwater during wet weather (usually summer). It was speculated that the increase in unbiodegradable particulate COD may be in the form of very fine soil particles (e.g. colloids comprised partly of humic acids) which do not settle in the primary sedimentation tanks, but do contribute COD and become trapped in the activated sludge flocs].

- Satisfactory prediction of P removal (see below) was obtained for most periods using values for $\mathrm{S}_{\mathrm{A}}$ derived from the known acetate concentrations added to the influent. However, for certain periods (Periods 3.4.1 to 3.4.4), it was necessary to reduce the modelled $\mathrm{S}_{\mathrm{A}}$ concentration in order to improve agreement between predicted and observed $\mathrm{P}$ removal. It is unclear why this effect was observed. One possibility is that the very dilute sewage of these periods (due to high rainfall in the catchment) was slightly aerobic and may have contained significant concentrations of heterotrophic biomass. This biomass may have utilised some of the acetate over the two day period during which each sewage batch remained in the influent tank (at $\left.4^{\circ} \mathrm{C}\right)$. [Alternatively, some other influent component (e.g. aqueous sulphides) may have inhibited the BEPR mechanism during these periods. This possibility was discussed in Part 5 for Period 3.4.3 (De Haas et al., 2001a) during which fractionation studies showed a distinctly lower "biological $P$ " component in the control, relative to the test system].

- Suspected problems with the TKN determination were noted during examination of mass balances in Parts 3, 4 and 5 (De Haas et al., 2000c to d; 2001a). Influent TKN (or influent ammonia, $\mathrm{S}_{\mathrm{NH} 4}$ in the IAWQ model set up) were adjusted to improve agreement between observed and predicted effluent nitrate concentrations. In this manner, overall agreement between observed and predicted nitrate concentrations in all the reactors was also improved. For all experimental periods, it was found that this approach gave predicted effluent (or second aerobic reactor) nitrate concentrations which were within $\sim 1 \mathrm{mg} \mathrm{N} / \ell$ of the observed value. Using the steady-state model of Wentzel et al. (1990) it can be shown that nitrate variation of this order would affect the BEPR potential of the system used here by approximately $<1 \mathrm{mgP} / \ell$, which is well within the standard deviation of effluent total $\mathrm{P}$ concentrations observed for most experimental periods (De Haas et al., 2000c to d; 2001a).

- The maximum specific growth rate of the nitrifiers $\left(\mathrm{m}_{\mathrm{AUT}}\right.$ at $20^{\circ} \mathrm{C}$ ) required to achieve good agreement between predicted and observed effluent ammonia concentrations was varied over the range 0.23 to 0.48 (mean 0.37 ) $\mathrm{d}^{-1}$ This appeared to be acceptable on the basis of the range suggested for this model parameter by WRC (1984). [For low concentrations of ammonia in nitrifying systems, a relatively large change in $m_{A U T}$ is necessary to effect a small change in the effluent ammonia concentration. Although not followed here, an alternative approach would be to change the value of the half-saturation coefficient for the nitrifiers (autotrophs, i.e. $K_{S A}$ ), for which the default value is $1 \mathrm{mg} \mathrm{N} / \ell$ (Wentzel et al., 1992)].

\section{Results for control unit (R2)}

Key results for the calibration of the IAWQ model to the observed data for the control unit (R2) are summarised in Appendix A (Table A1). The predicted and observed effluent $P$ results are graphed in Fig. 1. Agreement between predicted and observed values for effluent (total) $\mathrm{P}$ was generally better than $1 \mathrm{mgP} / \ell$. As outlined in the Modelling Method, this was achieved by manipulation of the defined influent characteristics (Table 1).

A more consistent set of influent characteristics could not be used because of the variability of the sewage component of the influent. That the composition of the sewage did vary considerably was evident from the relatively large standard deviations in the observed biological P removal data (refer to Appendix A in each of Parts 3, 4 \& 5 - De Haas et al., 2000c to d; 2001a). This problem reflects a shortcoming in the experimental set-up in this study, stemming from the relatively weak and variable composition of source sewage used (refer to Part 3 - De Haas, 2000c). Despite the variability in influent sewage composition, reasonably close correlation between predicted and measured values was obtained, except for anaerobic $\mathrm{P}$ concentrations.

With few exceptions, in this investigation the IAWQ model predicted anaerobic reactor soluble $\mathrm{P}$ concentrations were less (14\% less on average) than the observed filtered total $\mathrm{P}$ concentrations for this reactor [data not shown]. At lower influent $\mathrm{P}$ concentrations $(<20 \mathrm{mgP} / \ell)$, the agreement appeared to be better. Moreover, for two experimental periods with stable pilot plant operation, low effluent $P$ concentrations and good $P$ and COD mass balances, agreement (to within $2 \%$ ) between the observed and predicted anaerobic P concentrations was obtained. However, in the upper range, the difference between observed filtered total $\mathrm{P}$ and predicted soluble $\mathrm{P}$ concentrations for the anaerobic reactor was $\sim 10$ to $20 \mathrm{mg} / \ell$. Initially it was thought that this difference may have arisen because measured $\mathrm{P}$ concentrations were total soluble $\mathrm{P}$, whereas the predicted concentration is the sum of the phosphate weak acid/base species (i.e. $\mathrm{H}_{3} \mathrm{PO}_{4}+\mathrm{H}_{2} \mathrm{PO}_{4}^{-}+\mathrm{HPO}_{4}{ }^{2-}+\mathrm{PO}_{4}^{3-}$ ); thus, the difference may be due to bonded soluble $\mathrm{P}$ (soluble organic $\mathrm{P}$ or polyP) entering the anaerobic reactor with the influent. The influent total $P$ of municipal wastewater may be approximated as the influent soluble orthoP plus soluble polyP of detergent origin; the organic $\mathrm{P}$ fractions are relatively insignificant (Henze et al., 1995). Hence, if the difference between measured and predicted anaerobic concentrations is due to the different forms of $\mathrm{P}$, then this difference must arise principally from polyP of influent origin. Such large differences cannot be adequately explained on the basis of influent polyP of laundry detergent origin: for Darvill settled sewage, the difference between total $\mathrm{P}$ and orthoP concentrations was of the order of 3 to $4 \mathrm{mgP} / \ell$. Further research with enhanced cultures and recalibration of the models would need to be undertaken to explain the differences between predicted and observed Prelease data. Since the model predictions for effluent $P$ concentrations had been matched to those observed for the control unit, the differences noted for the steady state anaerobic reactor $\mathrm{P}$ concentration were not expected to impact significantly on predictions of system $\mathrm{P}$ removal with chemical dosing. Theoretically, the reactor orthoP concentration can influence the rate of metal phosphate precipitation in IAWQ precipitation model formulation, but using the IAWQ default values for rates of precipitation/ dissolution (Henze et al., 
TABLE 1

Influent sewage composition and parameters assumed for IAWQ modelling of selected pilot plant experimental periods of this study.

\begin{tabular}{|c|c|c|c|c|c|c|c|c|c|c|c|c|c|c|c|c|c|c|}
\hline Period & $\begin{array}{c}\mathrm{S}_{\mathrm{TcoD}}\left(\mathrm{S}_{\mathrm{t}}\right) \\
\mathrm{mg} / \ell \\
\mathrm{COD}\end{array}$ & $\begin{array}{l}\mathrm{S}_{\mathrm{A}} \\
\mathrm{mg} / \ell \\
\mathrm{COD}\end{array}$ & $\begin{array}{l}\mathrm{S}_{\mathrm{F}} \\
\mathrm{mg} / \ell \\
\mathrm{COD}\end{array}$ & $\begin{array}{l}\mathrm{s}_{1} \\
\mathrm{mg} / \ell \\
\mathrm{COD}\end{array}$ & $\begin{array}{l}\mathrm{X}_{1} \\
\mathrm{mg} / \ell \\
\mathrm{COD}\end{array}$ & $\begin{array}{l}\mathrm{x}_{\mathrm{s}} \\
\mathrm{mg} / \ell \\
\mathrm{COD}\end{array}$ & $\begin{array}{c}\mathfrak{f}_{\mathrm{bs}} \text { ' } \\
\#\end{array}$ & $\begin{array}{c}\mathrm{f}_{\mathrm{ac}}{ }^{\prime} \\
\#\end{array}$ & $\begin{array}{c}\text { 'f }_{\mathrm{us}} \text { ' } \\
\#\end{array}$ & $\begin{array}{c}\text { 'f } f_{\mathrm{up}} \text { ' } \\
\#\end{array}$ & $\mathbf{i}_{\text {NSI }}$ & $\begin{array}{c}\mathrm{S}_{\mathrm{NH} 4} \\
\mathrm{mgN} / \ell\end{array}$ & $\begin{array}{c}\text { Modelled } \\
\mathrm{C}_{\mathrm{TKN}}(\mathrm{Nti}) \\
\mathrm{mgN} / \ell \\
\# \#\end{array}$ & $\begin{array}{c}\text { Measured } \\
\mathrm{C}_{\mathrm{TKN}}(\mathrm{Nti}) \\
\mathrm{mgN} / \ell\end{array}$ & $\begin{array}{c}\text { Modelled } \\
\mathrm{N}_{\mathrm{ti}} / \mathrm{S}_{\mathrm{ti}} \\
\mathrm{mgN} / \\
\mathrm{mgCOD}\end{array}$ & $\begin{array}{l}\mathrm{P}_{\mathrm{ti}} \\
\text { or } \mathrm{C}_{\mathrm{TP}} \\
\mathrm{mgP} / \ell\end{array}$ & $\begin{array}{l}\mathrm{m}_{\mathrm{AUT}} \\
\mathrm{d}-1\end{array}$ & $\begin{array}{r}\mathrm{Y}_{\mathrm{pO}} \\
\mathrm{mgP} / \\
\mathrm{mg} \text { COD }\end{array}$ \\
\hline 3.2 .2 & 478 & 150 & 180 & 24 & 14 & 110 & 0.75 & 0.46 & 0.05 & 0.03 & 0.11 & 15.6 & 29.0 & 40.3 & 0.06 & 53.06 & 0.36 & 0.57 \\
\hline 3.2 .3 & 379 & 150 & 117 & 19 & 27 & 67 & 0.80 & 0.56 & 0.05 & 0.07 & 0.15 & 22.8 & 33.6 & 38.3 & 0.09 & 49.67 & 0.3 & 0.52 \\
\hline 3.2 .4 & 346 & 148 & 126 & 17 & 28 & 27 & 0.91 & 0.54 & 0.05 & 0.08 & 0.08 & 19.5 & 27.7 & 38.3 & 0.08 & 49.00 & 0.25 & 0.53 \\
\hline 3.2 .5 & 251 & 149 & 42 & 16 & 13 & 31 & 0.86 & 0.78 & 0.06 & 0.05 & 0.11 & 19.2 & 24.3 & 31.9 & 0.10 & 46.71 & 0.32 & 0.52 \\
\hline 3.2 .7 & 350 & 148 & 81 & 18 & 11 & 93 & 0.78 & 0.59 & 0.05 & 0.03 & 0.11 & 19.5 & 28.3 & 31.0 & 0.08 & 47.02 & 0.45 & 0.57 \\
\hline $3.2 .8 \mathrm{a}$ & 317 & 151 & 100 & 16 & 16 & 34 & 0.88 & 0.60 & 0.05 & 0.05 & 0.13 & 17.6 & 25.1 & 27.0 & 0.08 & 45.31 & 0.32 & 0.56 \\
\hline $3.3 .1 \mathrm{~b}$ & 442 & 149 & 77 & 22 & 9 & 185 & 0.55 & 0.66 & 0.05 & 0.02 & 0.11 & 22.8 & 35.5 & 31.3 & 0.08 & 49.85 & 0.45 & 0.54 \\
\hline 3.3 .2 & 407 & 151 & 97 & 20 & 33 & 106 & 0.70 & 0.61 & 0.05 & 0.08 & 0.04 & 20.8 & 31.0 & 31.3 & 0.08 & 48.80 & 0.23 & 0.54 \\
\hline 3.3 .3 & 456 & 151 & 151 & 18 & 14 & 123 & 0.71 & 0.50 & 0.04 & 0.03 & 0.11 & 24.7 & 37.1 & 35.0 & 0.08 & 52.64 & 0.23 & 0.55 \\
\hline 3.3 .4 & 461 & 150 & 69 & 18 & 83 & 140 & 0.61 & 0.69 & 0.04 & 0.18 & 0.07 & 22.1 & 36.9 & 33.5 & 0.08 & 50.61 & 0.32 & 0.50 \\
\hline 3.3 .5 & 398 & 150 & 67 & 20 & 50 & 112 & 0.66 & 0.69 & 0.05 & 0.13 & 0.11 & 23.4 & 35.6 & 30.1 & 0.09 & 50.33 & 0.32 & 0.53 \\
\hline 3.3 .6 & 354 & 150 & 61 & 18 & 39 & 86 & 0.71 & 0.71 & 0.05 & 0.11 & 0.09 & 21.3 & 30.9 & 26.7 & 0.09 & 46.02 & 0.38 & 0.52 \\
\hline 3.6 .1 & 403 & 100 & 72 & 58 & 36 & 137 & 0.56 & 0.58 & 0.14 & 0.09 & 0.02 & 19.8 & 30.0 & 31.5 & 0.07 & 10.45 & 0.45 & 0.52 \\
\hline 3.6.2a & 427 & 100 & 87 & 43 & 17 & 180 & 0.51 & 0.54 & 0.1 & 0.04 & 0.02 & 19.5 & 32.2 & 31.8 & 0.08 & 10.46 & 0.45 & 0.50 \\
\hline 3.4 .1 & 237 & 107 & 24 & 14 & 36 & 56 & 0.70 & 0.82 & 0.06 & 0.15 & 0.06 & 11.4 & 17.7 & 15.4 & 0.07 & 43.57 & 0.35 & 0.51 \\
\hline 3.4 .2 & 284 & 114 & 28 & 14 & 11 & 116 & 0.55 & 0.80 & 0.05 & 0.04 & 0.06 & 15.6 & 22.8 & 18.0 & 0.08 & 44.22 & 0.35 & 0.53 \\
\hline 3.4 .3 & 264 & 100 & 25 & 16 & 8 & 115 & 0.52 & 0.80 & 0.06 & 0.03 & 0.13 & 13.3 & 21.3 & 15.6 & 0.08 & 42.90 & 0.42 & $\mathrm{R} 1: 0.51$ \\
\hline & & & & & & & & & & & & & & & & & & R2 $: 0.58$ \\
\hline 3.4 .4 & 323 & 136 & 15 & 19 & 8 & 145 & 0.51 & 0.90 & 0.06 & 0.03 & 0.11 & 20.5 & 29.4 & 26.6 & 0.09 & 16.58 & 0.48 & 0.57 \\
\hline 3.5 .1 & 278 & 20 & 34 & 19 & 42 & 163 & 0.25 & 0.37 & 0.07 & 0.15 & 0.1 & 23.4 & 35.8 & 34.1 & 0.13 & 9.91 & 0.48 & 0.55 \\
\hline 3.5 .2 & 341 & 20 & 60 & 23 & 24 & 215 & 0.27 & 0.25 & 0.07 & 0.07 & 0.14 & 21.5 & 36.7 & 35.7 & 0.11 & 10.77 & 0.48 & 0.47 \\
\hline Mean & 360 & 125 & 76 & 22 & 26 & 112 & 0.64 & 0.62 & 0.06 & 0.07 & 0.09 & 19.7 & 30.0 & 30.2 & 0.08 & 38.89 & 0.37 & 0.53 \\
\hline SD & 74 & 41 & 44 & 10 & 19 & 52 & 0.18 & 0.16 & 0.02 & 0.05 & 0.04 & 3.5 & 5.6 & 7.0 & 0.01 & 16.43 & 0.08 & 0.03 \\
\hline
\end{tabular}

\#: Not IAWQ symbols. Refer to Nomenclature.

\#\#: Calculated from: $\mathrm{C}_{\mathrm{TKN}}=\mathrm{S}_{\mathrm{NH} 4}+\left(\mathrm{X}_{\mathrm{I}} \cdot \mathrm{i}_{\mathrm{NXI}}\right)+\left(\mathrm{X}_{\mathrm{S}} \cdot \mathrm{i}_{\mathrm{NXS}}\right)+\left(\left\{\mathrm{X}_{\mathrm{H}}+\mathrm{X}_{\mathrm{PAO}}+\mathrm{X}_{\mathrm{A}}\right\} \cdot \mathrm{i}_{\mathrm{NBS}}\right)+\left(\mathrm{S}_{\mathrm{F}} \cdot \mathrm{i}_{\mathrm{NSP}}\right)+\left(\mathrm{S}_{\mathrm{I}} \cdot \mathrm{i}_{\mathrm{NSI}}\right)$ (Henze et al., 1995)

where $\left\{X_{\mathrm{H}}+\mathrm{X}_{\mathrm{PAO}}+\mathrm{X}_{\mathrm{A}}\right\}=0$ by assumption here. Values for $\mathrm{i}_{\mathrm{NXI}}, \mathrm{i}_{\mathrm{NXS}}, \mathrm{i}_{\mathrm{NSF}}$ as per Wentzel and Ekama (1995). 
IAWQ MODEL vS OBSERVED EFFLUENT ORTHO P

CONTROL UNIT (R2) - Without metal salt dosing

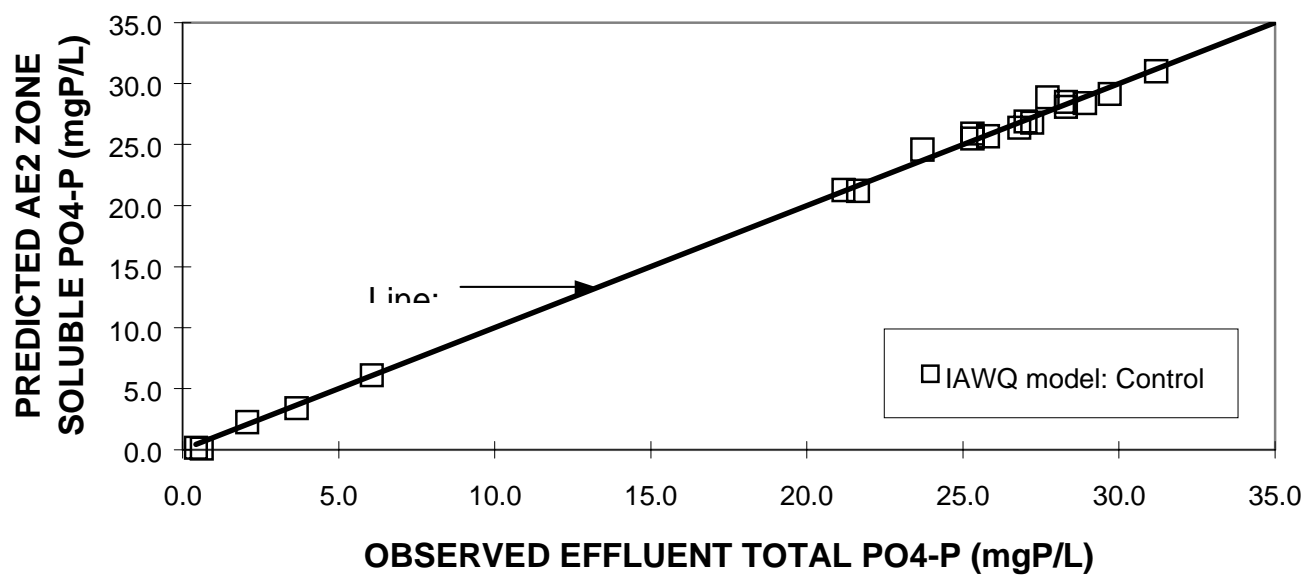

Figure 1

Correlation between observed and IAWQ model predicted effluent $P$

concentrations for the control unit (R2) for all experimental periods modelled in this study

IAWQ MODEL VS OBSERVED EFFLUENT ORTHO P TEST UNIT (R1) - With metal salt dosing

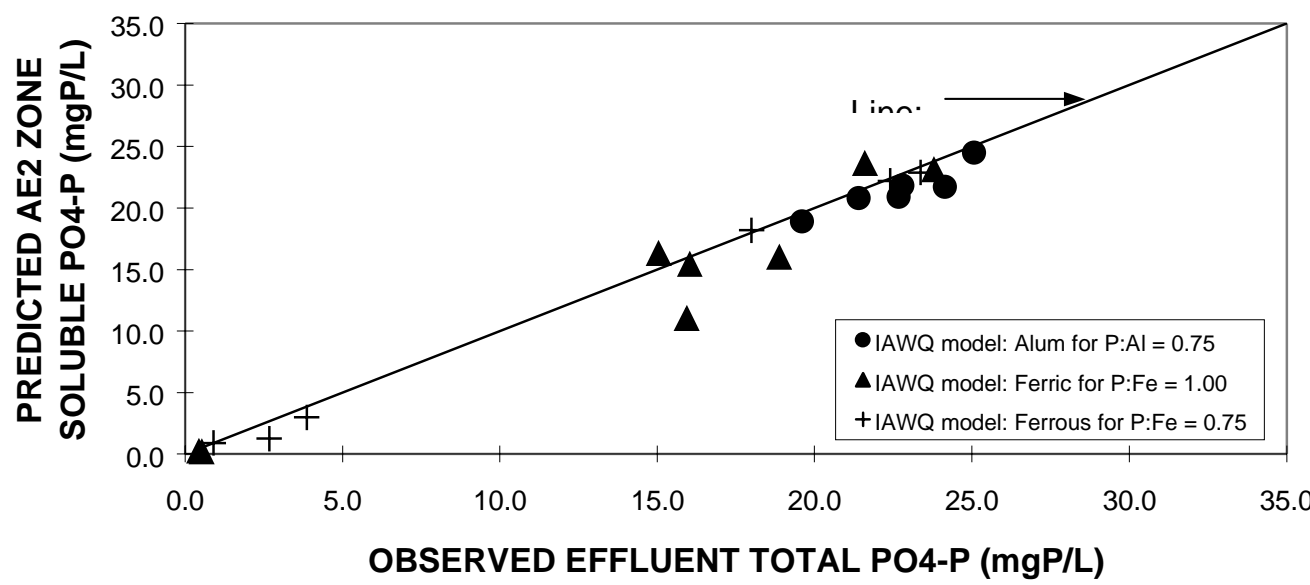

Figure 2

Correlation between observed and IAWQ model predicted effluent $P$ concentrations for the test unit (R1) - before manipulation of model precipitation/ redissolution stoichiometry for individual experimental periods

Figure 3

Correlation between observed and IAWQ model predicted effluent $P$ concentrations for the test unit (R1) - after manipulation of model precipitation/ redissolution stoichiometry for individual experimental periods 
1995), these model reactions proceed rapidly to virtual completion within realistic reactor retention times. Hence, in this formulation, the chemical $\mathrm{P}$ removal component is controlled mainly by stoichiometry, and it lowers the predicted steady-state orthoP concentration in all the reactors while the slower biological processes continue to establish the relative orthoP concentrations in the respective reactors. Where the kinetics of the precipitation/ dissolution processes are slowed (as discussed later in this paper), the precipitation rate may be controlled more heavily by the reactor soluble orthoP concentration. In this event, closer attention may need to be paid to calibrating the biological processes to match observed $\mathrm{P}$ release/uptake data more exactly.

\section{Results for test unit (R1)}

A comparison of the model predictions and observed data for the test unit is presented in Figs. 2 and 3, as well as Tables A2 and A3 (Appendix 1).

\section{Stoichiometry of chemical precipitation in IAWQ model}

The IAWQ model (Henze et al., 1995) only suggests stoichiometry for precipitation with ferric salts, as $1 \mathrm{~mol} \mathrm{P} / \mathrm{mol} \mathrm{Fe}$ (for $\mathrm{FePO}_{4}$ formation). During initial modelling attempts, the same P:metal (Me) stoichiometry was applied to periods in which either alum or ferrous-ferric chloride (ca. 90\% Fe[II] in blend) were dosed to the pilot plants. For alum and the ferrous-ferric chloride blend, it was found that the assumed 1:1 P:Me stoichiometry resulted in overprediction of the additional $P$ removal found in the test unit (metal dosed) relative to the control. That is, predicted effluent $\mathrm{P}$ concentrations were lower than those observed for the test unit. Improved predictions resulted when the model P:Me stoichiometry was adjusted to ca. $0.75 \mathrm{~mol} \mathrm{P} / \mathrm{mol} \mathrm{Me}$ for alum and ferrous-ferric chloride (blend) dosing (Fig. 2; Table A2). Further improvements in the agreement between predicted and observed effluent $\mathrm{P}$ concentrations could be obtained by manipulating the stoichiometry for individual experimental periods (Fig. 3; Table A3).

In order to provide a systematic method for adjusting the stoichiometry of the precipitation and redissolution processes in the IAWQ model, the general formula for precipitate of $\mathrm{Me}_{\mathrm{r}} \mathrm{PO}_{4} \mathrm{OH}_{(3 \mathrm{r}-3)}$ (from Luedecke et al., 1989) was accepted, where $\mathrm{Me}$ is a trivalent metal ion $\left(\mathrm{Al}^{3+}\right.$ or $\left.\mathrm{Fe}^{3+}\right)$ and ' $\mathrm{r}$ ' is the Me:P molar ratio. This allowed the stoichiometric constants for the metal (hydroxy) phosphate and metal hydroxide precipitates to be calculated in accordance with those suggested for $\mathrm{FePO}_{4}$ by Henze et al. (1995). As an example, the values for aluminium (hydroxy) phosphate are given in Table 3. It is a simple matter to perform similar calculations for ferric hydroxy-phosphates. For experimental periods using the ferrous-ferric chloride blend, it was assumed that the ferrous ions were completely oxidised to ferric form before precipitation. [Experimental evidence suggests that such oxidation does take place under aerobic conditions in activated sludge systems, but there is also evidence that ferrous phosphate (or other forms of ferrous precipitate) occurs in such systems, particularly in anaerobic reactors (De Haas et al., 2000a). However, a generic formula for precipitates of mixed iron valency would be more complex; no advantage could be found at this stage for adding such complexity. Rather, adoption of a lower Me:P stoichiometry for periods with addition of ferrous ions appeared to be adequate and may, in fact, be partly due to precipitation offerrous phosphate, or other amorphous iron phosphates].
It should be noted that the method given by Henze et al. (1995) for estimating additional TSS production (i.e. additional inorganic suspended solids, or ISS) does not take into account the expected change of residual metal hydroxide to metal oxide upon ashing at $550^{\circ} \mathrm{C}$. This aspect is commented upon below in the context of ISS predictions.

\section{Adopted precipitation stoichiometry vs. apparent BEPR mechanism inhibition}

Table 4 gives the values for precipitation stoichiometry in the IAWQ model that were adopted on the basis of an acceptable fit to the observed data. Model predictions and observed data for key variables are given in Appendix A before and after manipulation of the stoichiometry (Tables A2 and A3, respectively).

The values for the adopted P:Me stoichiometry may be compared with observed values, based on system $P$ removal or fractionation data relative to metal dose (Table 4). For certain periods, there are obvious discrepancies. For example, for Periods 3.2.3 and 3.2.4, the stoichiometry modelled was similar to that from fractionation, but was higher than that from the difference in observed $P$ removal $\left(\mathrm{DP}_{\text {trem }}\right.$ ) between the test and control units. As discussed in Part 3 (De Haas et al., 2000c), large variance in the $\mathrm{DP}_{\text {trem }}$ data for these periods (at low alum dose) lessens confidence in these data. Similarly, in Period 3.4.3, apparent inhibition of the BEPR mechanism was noted for the control unit (De Haas et al., 2001a). In the model, allowance was made for this by adopting a higher value for $\mathrm{Y}_{\mathrm{PO} 4}$ for the control(R2) (Table 1). Again, the stoichiometry estimate based on $\mathrm{DP}_{\text {tem }}$ data for this period cannot be considered to be reliable (Table 4).

Considering the practical constraints of precisely matching the model and observed data, the following general conclusions may be drawn from Tables 4 and 5:

- Fairly good overall agreement between the adopted and observed $\mathrm{P} / \mathrm{Me}$ stoichiometry was obtained, assuming all metal ions dosed are available for precipitation [i.e. ignoring possible loss of metal ions through complexation with organics in the mixed liquor matrix].

- The model is not capable of predicting apparent inhibition (depression) by chemical dosing of the BEPR mechanism in the absence of P limitation. [De Haas et al. (2000c to d; 2001a) reported that approximately 3 to $24 \%$ apparent inhibition of the BEPR mechanism was observed in the absence of $P$ limitation for the range of metal salt doses examined. However, the IAWQ precipitation model assumes that the chemical and biological $P$ removal mechanisms operate independently of each other, except in respect of reactor soluble orthoP concentration $\left(S_{\mathrm{PO}_{4}}\right)$. If $S_{\mathrm{PO} 4}$ is not limiting, no interaction between the two mechanisms is predicted. To account for partial inhibition of the BEPR mechanism relative to the actual stoichiometry, one would expect that a lower model P/Me stoichiometry is required in order to match the observed and predicted system $P$ removal. However, in several cases (e.g. Periods 3.3.1. 3.3.2, 3.3.3, 3.4.2, 3.4.4), the model input stoichiometrywas higher than that estimated from fractionation data. This probably reflects the failure of the fractionation procedure to fully recover the chemical $P$ fraction from the sludge matrix and, hence, to account for the additional $P$ removal in the test unit, relative to the control. This possibility was discussed in Part 4 (De Haas, 2000d)].

- For modelling purposes, the choice of precipitation stoichiometry should take into account depression of the BEPR 


\begin{tabular}{|c|c|c|c|c|}
\hline \multicolumn{5}{|c|}{$\begin{array}{l}\text { TABLE } 3 \\
\begin{array}{c}\text { Example calculation of stoichiometric constants for precipitation and redissolution as } \\
\text { input to the IAWQ model }\end{array}\end{array}$} \\
\hline \multicolumn{5}{|c|}{ Reaction: $\mathrm{PO}_{4}{ }^{3-}+\mathrm{Al}(\mathrm{OH})_{3}{ }^{\circledR} \mathrm{AlPO}_{4}+3 \mathrm{OH}$ when $\mathrm{r}=1 ; \mathrm{P} / \mathrm{Al}=1$} \\
\hline $\begin{array}{l}\text { Stoichiometry } \\
\mathrm{mgP} / \ell\end{array}$ & $\begin{array}{l}\mathrm{S}_{\mathrm{pO} 4} \\
\mathrm{mg} / \ell \text { as } \\
\mathrm{Al}(\mathrm{OH})_{3}\end{array}$ & $\begin{array}{l}\mathrm{X}_{\mathrm{MeOH}} \\
\mathrm{mg} / \ell \text { as } \\
\mathrm{AIPO}_{4}\end{array}$ & $\begin{array}{l}\mathrm{X}_{\mathrm{MeP}} \\
\mathrm{mg} / \ell \text { as } \\
\text { TSS }\end{array}$ & $\mathbf{X}_{\text {TSS }}$ \\
\hline $\begin{array}{l}\text { Precipitation } \\
\text { Redissolution }\end{array}$ & $\begin{array}{l}-1 \\
+1\end{array}$ & $\begin{array}{l}-2.52 \\
+2.52\end{array}$ & $\begin{array}{l}+3.94 \\
-3.94\end{array}$ & $\begin{array}{l}+1.42 \\
-1.42\end{array}$ \\
\hline Stoichiometry & $\begin{array}{c}\mathrm{S}_{\mathrm{po} 4} \\
\mathrm{mmol} / \ell \text { as } \mathrm{P}\end{array}$ & $\begin{array}{c}\mathrm{X}_{\mathrm{MeOH}} \\
\mathrm{mmol} / \ell \text { as Al(OH) })_{3}\end{array}$ & $\begin{array}{c}\mathrm{X}_{\text {MeP }} \\
\mathrm{mmol} / \ell \text { as AIPO } \\
\end{array}$ & \\
\hline $\begin{array}{l}\text { Precipitation } \\
\text { Redissolution }\end{array}$ & $\begin{array}{l}-0.032 \\
+0.032\end{array}$ & $\begin{array}{l}-0.032 \\
+0.032\end{array}$ & $\begin{array}{l}+0.032 \\
-0.032\end{array}$ & \\
\hline \multicolumn{5}{|c|}{ 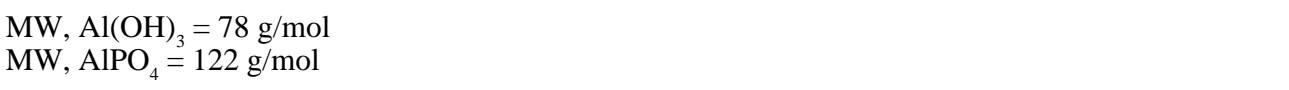 } \\
\hline \multicolumn{5}{|c|}{ Reaction: $\mathrm{PO}_{4}{ }^{3-}+1.33 \mathrm{Al}(\mathrm{OH})_{3}{ }^{\circledR} \mathrm{Al}_{1.33} \mathrm{PO}_{4} \mathrm{OH}+3 \mathrm{OH}$ when $\mathrm{r}=1.33 ; \mathrm{P} / \mathrm{Al}=0.75$} \\
\hline Stoichiometry & $\underset{\mathrm{SgO} / \ell}{\mathrm{SgP}_{\mathrm{P}}}$ & $\begin{array}{l}\mathrm{X}_{\text {MeOH }} \\
\mathrm{mg} / \ell \text { as Al(OH) } \\
\mathrm{PO}_{4} \mathrm{OH} \\
\end{array}$ & $\begin{array}{c}\mathrm{X}_{\mathrm{MeP}} \\
\mathrm{mg} / \ell \text { as } \mathrm{Al}_{1.33}\end{array}$ & $\begin{array}{c}\mathrm{x}_{\mathrm{TSS}} \\
\mathrm{mg} / \ell \text { as TSS }\end{array}$ \\
\hline $\begin{array}{l}\text { Precipitation } \\
\text { Redissolution }\end{array}$ & $\begin{array}{l}-0.75 \\
+0.75\end{array}$ & $\begin{array}{l}-2.52 \\
+2.52\end{array}$ & $\begin{array}{l}+3.58 \\
-3.58\end{array}$ & $\begin{array}{l}+1.06 \\
-1.06\end{array}$ \\
\hline Stoichiometry & $\begin{array}{c}\mathrm{S}_{\mathrm{po} 4} \\
\mathrm{mmol} / \ell \text { as } \mathrm{P}\end{array}$ & $\underset{\mathrm{mmol} / \ell \mathrm{as} \mathrm{Al}(\mathrm{OH})_{3}}{\mathrm{X}_{\mathrm{MeOH}}}$ & $\begin{array}{c}\mathrm{X}_{\mathrm{MeP}} \\
\mathrm{mmol} / \ell \text { as }_{\mathrm{Al}_{1.33} \mathrm{PO}_{4} \mathrm{OH}}\end{array}$ & \\
\hline $\begin{array}{l}\text { Precipitation } \\
\text { Redissolution }\end{array}$ & $\begin{array}{l}-0.024 \\
+0.024\end{array}$ & $\begin{array}{l}-0.032 \\
+0.032\end{array}$ & $\begin{array}{l}+0.024 \\
-0.024\end{array}$ & \\
\hline \multicolumn{5}{|c|}{$\begin{array}{l}\mathrm{MW}, \mathrm{Al}(\mathrm{OH})_{3}=78 \mathrm{~g} / \mathrm{mol} \\
\mathrm{MW}, \mathrm{Al}_{1.33} \mathrm{PO}_{4} \mathrm{OH}=148 \mathrm{~g} / \mathrm{mol}\end{array}$} \\
\hline
\end{tabular}

mechanism in the presence of metal dosing. From the results of this study, a selection of $\mathrm{P} / \mathrm{Me}$ stoichiometry in the following ranges appears to meet this requirement for periods without $P$ limitation:

\section{For alum at $20 \mathrm{~d}$ sludge age: 0.6 to 0.75}

For $\mathrm{FeCl}_{3}$ at $20 \mathrm{~d}$ sludge age: 1.0 (apparently no inhibition) For $\mathrm{FeCl}_{3}$ at $10 \mathrm{~d}$ sludge age: 0.6 (to 0.9 )

For $\mathrm{FeCl}_{2} / \mathrm{FeCl}_{3}$ blend at $10 \mathrm{~d}$ sludge age: 0.75

- Under P-limiting conditions, where virtually complete $\mathrm{P}$ removal was predicted (and observed) in both the test and control units (i.e. with or without metal salt addition respectively), the choice of model P/Me stoichiometry is less critical and may be guided by the fractionation data obtained in this study:

For $\mathrm{FeCl}_{3}$ and/or $\mathrm{FeCl}_{2}$ at 10 day sludge age: 0.3 to 0.6

- The model does predict competition for available $\mathrm{P}$ between the chemical and biological mechanisms. Under P-limiting conditions, the effect of changing the precipitation stoichiometry is to partition more or less P removal to one vs. the other mechanism. [This may be illustrated by examining the data presented in Table 5 for low effluent $P$ conditions. For example, in Periods 3.4.4, 3.5.1 and 3.5.2 with average effluent $P$ concentrations in the range ca. 3 to $4 \mathrm{mgP} / \mathrm{h}$, a change of model input stoichiometry from 0.3 (or 0.4 ) to 0.75 produced a change in predicted mixed liquor polyP concentrations of less than 10\%. For Periods 3.6.1 and 3.6.2 a where the average effluent $P$ concentrations were 0.2 to $0.6 \mathrm{mgP} / \mathrm{l}$ (or lower due to analytical detection limitations), a change of model input stoichiometry from 0.6 to 1.0 produced a change in predicted polyP of 18 to $20 \%$. As the P/Me stoichiometry is decreased, the residual metal hydroxide concentration decreases; although the mass of $P$ removed chemically is smaller, proportionately more metal is bound as metal hydroxy phosphate and less remains as metal hydroxide (Table 5)].

- Within the constraints of experimental observation in this study, it was not possible to exactly evaluate model performance under very low effluent $\mathrm{P}$ concentrations. [More care would need to be taken with $P$ measurements in the low range since actual effluent $P$ concentrations may fall below the detection limits of methods such as the automated molybdate method applied here]. For Periods 3.6.1 and 3.6.2a (with P limitation) the model predicted lower effluent $\mathrm{P}$ concentrations than the average measured values. Nevertheless, the model did predict slightly higher effluent $\mathrm{P}$ concentrations and lower poly $\mathrm{P}$ concentrations for the test unit (with $\mathrm{FeCl}_{3}$ dosing) relative to the control for these periods (Table 5). This is consistent with observations of weaker BEPR in the test unit, based on 


\begin{tabular}{|c|c|c|c|c|c|c|c|}
\hline \multicolumn{8}{|c|}{$\begin{array}{c}\text { TABLE } 4 \\
\text { Calibration of IAWQ model for precipitation stoichiometry }\end{array}$} \\
\hline \multirow[t]{2}{*}{ Period } & \multirow[t]{2}{*}{ Metal dosed } & \multirow{2}{*}{$\begin{array}{c}\text { Dose * } \\
\mathrm{mg} / \ell \text { as Me }\end{array}$} & \multirow{2}{*}{$\begin{array}{l}\text { Sludge } \\
\text { age (d) }\end{array}$} & \multirow{2}{*}{$\begin{array}{c}\text { Zone } \\
\text { dosed ** }\end{array}$} & \multicolumn{3}{|c|}{ P:Me stoichiometry (mol P/mol Me) * } \\
\hline & & & & & $\begin{array}{l}\text { Model } \\
\text { input }\end{array}$ & $\begin{array}{c}\text { Observed } \\
\mathrm{DP}_{\text {trem }} / \mathrm{Me}_{\star \star \star}^{\text {dosed }}\end{array}$ & $\begin{array}{c}\text { Observed } \\
\text { fractionation } \\
\text { OrthoP/Me } / \mathrm{dosed}_{\text {dos }}\end{array}$ \\
\hline 3.2 .2 & $\mathrm{Al}$ & 4.8 & 20 & AE1 & 0.75 & 0.70 & No data \\
\hline 3.2 .3 & $\mathrm{Al}$ & 4.7 & 20 & AE1 & 0.60 & 0.34 & 0.73 \\
\hline 3.2 .4 & $\mathrm{Al}$ & 4.7 & 20 & AN & 0.60 & 0.18 & 0.72 \\
\hline 3.2 .5 & $\mathrm{Al}$ & 9.2 & 20 & AN & 0.60 & 0.57 & 0.58 \\
\hline 3.2 .7 & $\mathrm{Al}$ & 9.2 & 20 & AE1 & 0.75 & 0.62 & 0.61 (a) \\
\hline $3.2 .8 \mathrm{a}$ & $\mathrm{Al}$ & 9.2 & 20 & AE1 & 0.75 & 0.69 & 0.62 \\
\hline 3.3.1(b) & $\mathrm{Fe}(\mathrm{III})$ & 10.3 & 20 & AE1 & 1.00 & 1.02 & 0.72 \\
\hline 3.3 .2 & $\mathrm{Fe}(\mathrm{III})$ & 20.8 & 20 & AE1 & 1.00 & 1.03 & 0.60 \\
\hline 3.3 .3 & $\mathrm{Fe}(\mathrm{III})$ & 10.3 & 20 & AN & 1.00 & 0.82 & 0.57 \\
\hline 3.3.4 & $\mathrm{Fe}(\mathrm{III})$ & 10.3 & 10 & AN & 0.60 & 0.37 & No data \\
\hline 3.3 .5 & $\mathrm{Fe}(\mathrm{III})$ & 20.4 & 10 & AN & 0.90 & 0.80 & No data \\
\hline 3.3.6 & $\mathrm{Fe}(\mathrm{III})$ & 20.5 & 10 & AE1 & 0.50 & 0.52 & No data \\
\hline 3.4 .1 & $\mathrm{Fe}(\mathrm{II})+\mathrm{Fe}(\mathrm{III})$ & 19.3 & 10 & AE1 & 0.75 & 0.74 & $1.37(\mathrm{c})$ \\
\hline 3.4 .2 & $\mathrm{Fe}(\mathrm{II})+\mathrm{Fe}(\mathrm{III})$ & 9.7 & 10 & AE1 & 0.75 & 0.62 & 0.49 \\
\hline 3.4 .3 & $\mathrm{Fe}(\mathrm{II})+\mathrm{Fe}(\mathrm{III})$ & 9.4 & 10 & $\mathrm{AN}$ & 0.75 & $1.75(\mathrm{~d})$ & 0.68 \\
\hline 3.4 .4 & $\mathrm{Fe}(\mathrm{II})+\mathrm{Fe}(\mathrm{III})$ & 9.6 & 10 & AE1 & 0.40 & $0.23(b)$ & $0.26(\mathrm{e})$ \\
\hline 3.5 .1 & $\mathrm{Fe}(\mathrm{II})+\mathrm{Fe}(\mathrm{III})$ & 9.6 & 10 & AE1 & 0.40 & 0.41 (b) & 0.40 \\
\hline 3.5 .2 & $\mathrm{Fe}(\mathrm{II})+\mathrm{Fe}(\mathrm{III})$ & 9.5 & 10 & AN & 0.30 & $0.21(b)$ & 0.37 \\
\hline 3.6 .1 & $\mathrm{Fe}(\mathrm{III})$ & 10.4 & 10 & AE1 & (0.40 to) 0.60 & $-0.03(b)$ & 0.38 \\
\hline 3.6.2a & $\mathrm{Fe}(\mathrm{III})$ & 10.4 & 10 & AE1 & (0.40 to) 0.60 & $-0.03(b)$ & 0.43 \\
\hline \multicolumn{8}{|c|}{$\begin{array}{l}\text { * Me : Al for alum; Fe for ferric chloride or ferrous-ferric chloride (blend) } \\
\text { ** Zones: AN = Anaerobic; AE1 } 1^{\text {st }} \text { Aerobic } \\
\text { *** } \mathrm{DP}_{\text {trem }} \text { : Difference in total P removal between test and control units (refer to De Haas et al., 2000c to d; 2001a) } \\
\text { (a) No fractionation data for Period 3.2.7. Data given for Period 3.2.6 (similar operating conditions). } \\
\text { (b) P limited experimental conditions; model predictions not very sensitive to input stoichiometry. } \\
\text { (c) Transition period from ferric chloride dosing : high VSS in test reactor influenced fractionation results } \\
\text { (De Haas et al., 2001a). } \\
\text { (d) Apparent Inhibition of BEPR removal in control reactor (De Haas et al., 2001a). } \\
\text { (e) Last of three fractionation runs taken at end of Period 3.4.4 taken as closest to steady-state for mixed liquor solids }\end{array}$} \\
\hline
\end{tabular}

fractionation data and $\mathrm{P}$ removal behaviour immediately after lifting P limitation (De Haas et al., 2000d).

- Reasonably good agreement was obtained between predicted and estimated values for polyP and MeP, based on fractionation data. $P$ mass balance issues and the small number of fractionation runs per experimental period are constraints when comparing the data sets. The polyP data are considered further below. Agreement for MeP could be improved if the same stoichiometry used in the model was applied to the fractionation results. This reflects a degree of uncertainty over whether all metal dosed is truly available for the precipitation (as opposed to complexation with other components of the sludge matrix) and the true recovery of the "chemical P" in fractionation procedure.

\section{Poly-P results}

In Fig. 4, the relationship between modelled and observed (fractionation) polyP content of the mixed liquor is graphed.
The following constraints need to be considered when interpreting Fig. 4:

- The model was calibrated to give close similarity between predicted effluent $\mathrm{S}_{\mathrm{PO} 4}$ and observed effluent total P. This ruled out the impact of solids loss in the effluent on the comparison of results, since the model assumes no solids loss in the effluent. Effluent total $\mathrm{P}$ was also used in mass balance calculations from observed data.

- Agreement between modelled and observed data is limited by the deviation from $100 \%$ of mass balances from observed data (especially for $\mathrm{P}$ and COD); the model assumes a mass balance of $100 \%$. Overall, P mass balances for the experimental periods gave the following results (mean $\pm \mathrm{SD}$ ):

Alum dosing periods: $88 \%( \pm 19)$

Ferric dosing periods: $98 \%( \pm 14)$

Ferrous dosing periods: $121 \%( \pm 34)$

- The modelling is heavily influenced by COD mass balance accuracy, particularly since $\mathrm{f}_{\text {up }}$ is not measured, but treated as 


\begin{tabular}{|c|c|c|c|c|c|c|c|c|}
\hline \multicolumn{9}{|c|}{$\begin{array}{c}\text { TABLE } 5 \\
\begin{array}{c}\text { Comparison of IAWQ model predicted and observed data for P-related compounds during } \\
\text { experimental periods with relatively low effluent } P \text { concentrations }\end{array}\end{array}$} \\
\hline Period & Unit & $\begin{array}{l}\text { Observed/ } \\
\text { Model }\end{array}$ & $\begin{array}{c}\text { Model P/Me } \\
\text { input } \\
\text { stoichiometry } \\
\text { adopted } \\
\text { molP/ } \\
\text { mol Me }\end{array}$ & $\begin{array}{c}\text { Effluent } \\
\mathrm{S}_{\mathrm{TP}} \\
\mathrm{mgP} / / \mathrm{v}\end{array}$ & $\begin{array}{c}\text { Effluent } \\
\mathrm{S}_{\mathrm{PO}} \\
\mathrm{mgP} / \ell\end{array}$ & $\begin{array}{l}\text { Mixed } \\
\text { liquor } \\
\text { PolyP } \\
\text { mgP/l }\end{array}$ & 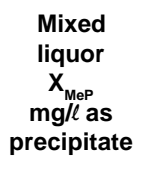 & 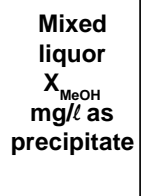 \\
\hline \multirow[t]{2}{*}{3.4 .4} & Test & $\begin{array}{l}\text { Model } \\
\text { Model } \\
\text { Obs. }\end{array}$ & $\begin{array}{l}0.75 \\
0.40 \\
-\end{array}$ & - & $\begin{array}{c}0.9 \\
1.3 \\
\mathbf{1 . 1 4}\end{array}$ & $\begin{array}{l}116 \\
120 \\
82 *\end{array}$ & $\begin{array}{c}221 \\
201 \\
\mathbf{2 3 0}^{*}\end{array}$ & $\begin{array}{c}47 \\
34 \\
\text { N/D }\end{array}$ \\
\hline & Control & $\begin{array}{l}\text { Model } \\
\text { Obs. }\end{array}$ & - & $-\overline{2.07}$ & $\begin{array}{l}2.26 \\
\mathbf{2 . 1 0}\end{array}$ & $\begin{array}{c}136 \\
116^{*}\end{array}$ & - & - \\
\hline \multirow[t]{2}{*}{3.5 .1} & Test & $\begin{array}{l}\text { Model } \\
\text { Model } \\
\text { Obs. }\end{array}$ & $\begin{array}{c}0.75 \\
0.40 \\
-\end{array}$ & $\begin{array}{c}- \\
- \\
3.87\end{array}$ & $\begin{array}{c}3.0 \\
4.2 \\
\mathbf{3 . 0 7}\end{array}$ & $\begin{array}{c}23 \\
24 \\
\mathbf{3 0}^{*}\end{array}$ & $\begin{array}{c}216 \\
209 \\
\mathbf{2 4 0}\end{array}$ & $\begin{array}{l}39 \\
27 \\
-\end{array}$ \\
\hline & Control & $\begin{array}{l}\text { Model } \\
\text { Obs. }\end{array}$ & - & 6.06 & $\begin{array}{c}6.1 \\
\mathbf{5 . 1 5}\end{array}$ & $\begin{array}{c}24 \\
31 *\end{array}$ & - & - \\
\hline \multirow[t]{2}{*}{3.5 .2} & Test & $\begin{array}{l}\text { Model } \\
\text { Model } \\
\text { Obs. }\end{array}$ & $\begin{array}{c}0.75 \\
0.30 \\
-\end{array}$ & $\begin{array}{c}- \\
- \\
2.68\end{array}$ & $\begin{array}{c}1.3 \\
2.2 \\
\mathbf{1 . 2 9}\end{array}$ & $\begin{array}{c}54 \\
60 \\
29 *\end{array}$ & $\begin{array}{c}186 \\
191 \\
\text { 236* }\end{array}$ & $\begin{array}{c}63 \\
37 \\
-\end{array}$ \\
\hline & Control & $\begin{array}{l}\text { Model } \\
\text { Obs. }\end{array}$ & - & - & $\begin{array}{c}3.4 \\
2.31\end{array}$ & $\begin{array}{c}61 \\
37^{*}\end{array}$ & - & - \\
\hline 3.6 .1 & $\begin{array}{l}\text { Test } \\
\text { Test }\end{array}$ & $\begin{array}{l}\text { Model } \\
\text { Model } \\
\text { Obs. }\end{array}$ & $\begin{array}{c}1.00 \\
0.60 \\
-\end{array}$ & $\begin{array}{c}- \\
- \\
0.45\end{array}$ & $\begin{array}{l}0.23 \\
0.15 \\
\mathbf{0 . 2 4}\end{array}$ & $\begin{array}{c}49 \\
60 \\
64 *\end{array}$ & $\begin{array}{c}177 \\
184 \\
257^{*}\end{array}$ & $\begin{array}{c}96 \\
73 \\
-\end{array}$ \\
\hline Control & Model & Obs. & - & $\begin{array}{l}0.16 \\
\mathbf{0 . 4 3}\end{array}$ & $\begin{array}{c}86 \\
0.21\end{array}$ & 93* & - & - \\
\hline \multirow[t]{2}{*}{$3.6 .2 \mathrm{a}$} & $\begin{array}{l}\text { Test } \\
\text { Test }\end{array}$ & $\begin{array}{l}\text { Model } \\
\text { Model } \\
\text { Obs. }\end{array}$ & $\begin{array}{c}1.00 \\
0.60 \\
-\end{array}$ & $\begin{array}{c}- \\
- \\
0.53\end{array}$ & $\begin{array}{l}0.17 \\
0.10 \\
\mathbf{0 . 4 4}\end{array}$ & $\begin{array}{r}47 \\
59 \\
\mathbf{5 1} *\end{array}$ & $\begin{array}{c}175 \\
182 \\
\mathbf{2 5 6}^{*}\end{array}$ & $\begin{array}{l}98 \\
75 \\
-\end{array}$ \\
\hline & Control & $\begin{array}{l}\text { Model } \\
\text { Obs. }\end{array}$ & - & $\begin{array}{c}- \\
0.62\end{array}$ & $\begin{array}{l}0.09 \\
\mathbf{0 . 4 4}\end{array}$ & $\begin{array}{c}84 \\
81 *\end{array}$ & - & - \\
\hline
\end{tabular}

a 'calibration constant' based on predicted vs. observed VSS. Manipulation of $f_{u p}$ influences the biodegradable COD fractions and, hence, affects biological $\mathrm{N} \& \mathrm{P}$ removal. [Normally the $N$ mass balance would also be important, but was less important here since influent TKN was manipulated to make effluent (last aerobic reactor) nitrate concentrations agree with observed values and hence minimise the impact on P removal predictions].

- The comparison also depends on P recovery (i.e. mass balance) for the fractionation procedure. The observed $\mathrm{P}$ recoveries from fractionation were in the range 91 to $114 \%$.

- The model does not make allowance for chemical P removal in the control unit. Fractionation suggested that ca. 10 to 30 $\mathrm{mgP} / \mathrm{gVSS}$ (10 to $15 \%$ of ML TP) in the control unit mixed liquor solids may be in the form of chemical precipitation/ complexation of $\mathrm{P}$, presumably incorporating metal ions from the influent. The model may over-predict polyP within this margin, compared with fractionation data. [Conceptually, in the model this precipitated orthoP fraction is effectively lumped with organic $P$ as the $P$ content of the various biomass fractions, notably $i_{P X I}$ and $i_{P B M}$. No attempt was made here to manipulate these model constants; the default values suggested by Henze et al. (1995) were accepted].

Given the above-mentioned experimental and modelling constraints, it may not be realistic to expect agreement between observed and predicted polyP to be better than within $\pm 20 \%$ when comparing fractionation and modelled results (refer to dotted lines in Fig. 4).

Figure 4 shows that two periods (3.3.3 and 3.2.8a) failed to give acceptable agreement (within a $20 \%$ tolerance) between predicted and observed polyP content for the control unit. In each case, these results stem from a single fractionation per experimental period. Furthermore, both of these periods had relatively poor mass balances for P and/or COD (refer to De Haas et al., 2000 c \& d). Period 3.3.3 presented settling problems apparently associated with poor sludge 
Figure 4

Model predictions for polyP versus observed data from sludge fractionation. An allowance of $10 \mathrm{mgP} / \mathrm{gVSS}$ was made for the nucleic acid $P$ content of the sludge in the estimation of polyP concentration from fractionation data (refer to De Haas et al., 2000a \& b)
IAWQ MODEL vS. FRACTIONATION DATA

POLY P (LAST AEROBIC REACTOR)

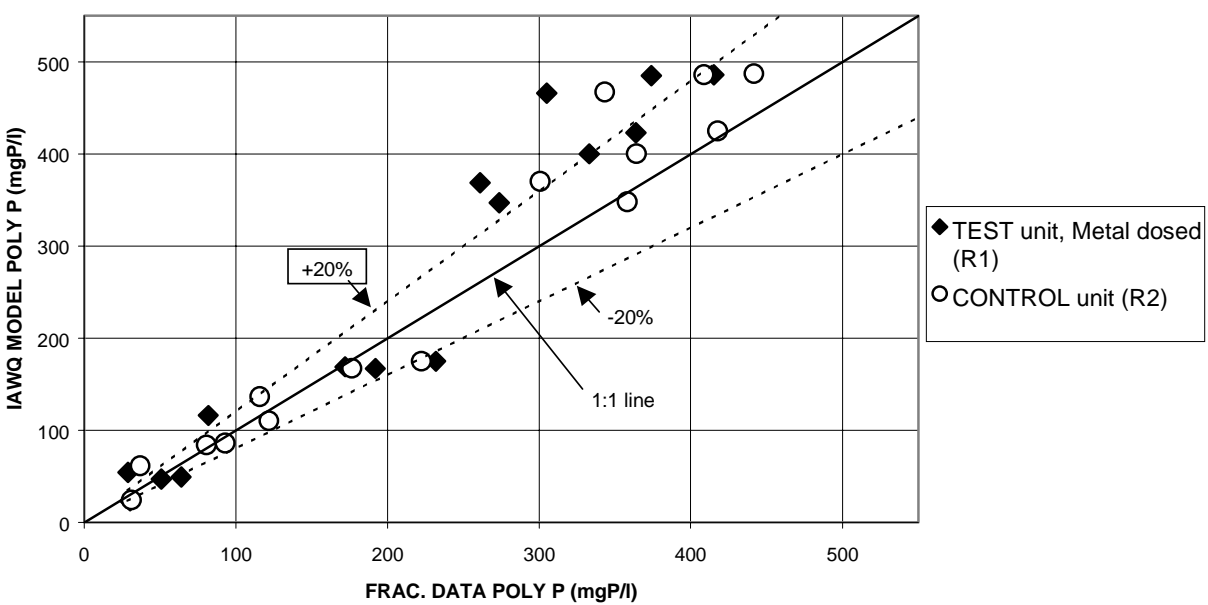

IAWQ Model vs. Observed ISS data

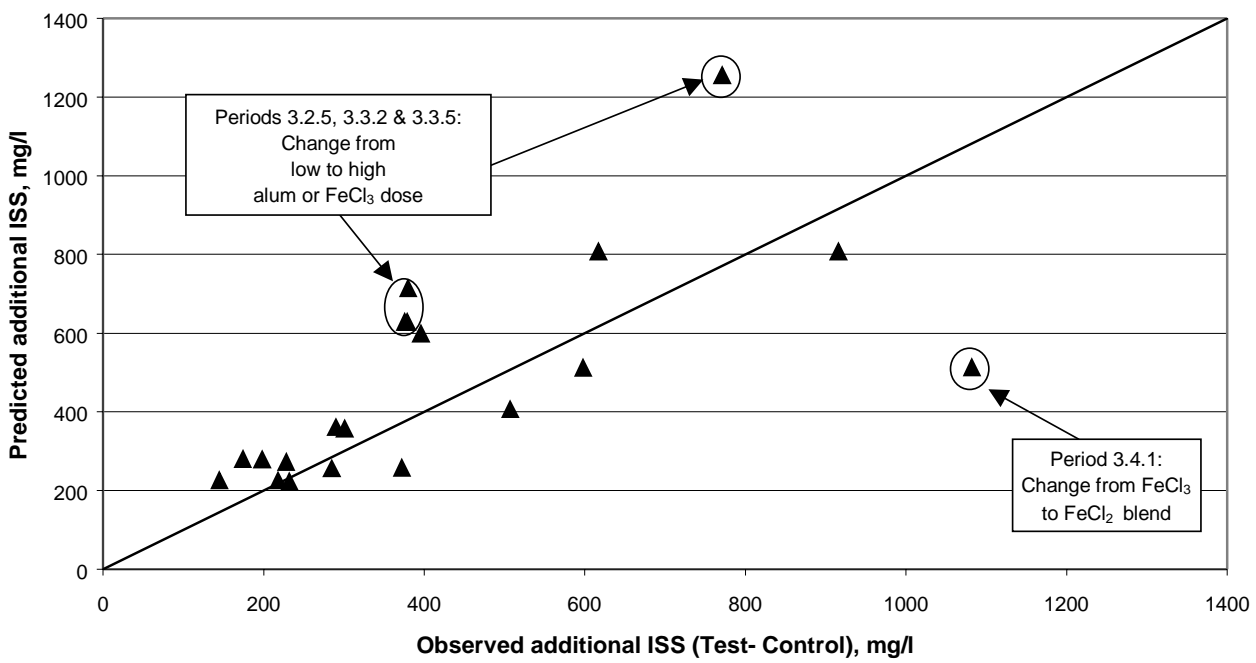

flocculation; Period 3.2.8a followed within two months of redevelopment of 'semi-enhanced' cultures. These factors could have contributed to a failure to reach 'steady-state' and hence detracted from the mass balances or observed polyP results.

Overall, subject to the constraints outlined above, Fig. 4 suggests that fairly good agreement between the predicted and observed polyP data was obtained. When $\mathrm{P}$ is limiting, the model appears to be able to predict competition for available $\mathrm{P}$ between the chemical and BEPR mechanisms fairly accurately. In the absence of $\mathrm{P}$ limitation, failure of the model to predict apparent 'inhibition' (or depression) of the BEPR mechanism is evident in Fig. 4: at higher polyP concentrations the points for the test unit (R1) lie horizontally to the left of those for the control (R2). Future versions of the model may need to incorporate a function for reducing the yield of polyP (e.g. by changing $\mathrm{Y}_{\mathrm{PO} 4}$ ) to take into account a depressed BEPR mechanism in the presence of metal ion addition, even where phosphate is not limiting.

\section{ISS results}

Chemical precipitate (ideally metal phosphate and/or metal hydroxide) will contribute directly to the inorganic suspended solids (ISS) content of the mixed liquor, and hence to the TSS. To determine inorganic suspended solids (ISS), the sample of filtered solids, which has been previously dried to a constant mass (at $105^{\circ} \mathrm{C}$ ) for the total suspended solids (TSS) determination, is ignited (at 550 to $600^{\circ} \mathrm{C}$ ) and the volatile suspended solids (VSS) mass loss is measured. By difference, ISS = TSS - VSS. During the ignition (ashing) process, it may be expected that metal phosphate will remain in this form, but metal hydroxide (e.g. $\mathrm{Al}(\mathrm{OH})_{3 \text {; }}$ $\left.\mathrm{Fe}(\mathrm{OH})_{3}\right)$ will be converted to metal oxide with the loss of water.

In the IAWQ chemical precipitation model, the conversion of metal hydroxide $(\mathrm{MeOH})$ to metal phosphate $(\mathrm{MeP})$ is modelled and the change in TSS expressed on the basis of the assumed stoichiometry. An inherent assumption in the IAWQ model is that $1 \mathrm{~g}$ of metal hydroxide contributes $1 \mathrm{~g}$ to TSS. Accordingly, the conversion of metal hydroxide to metal oxide during ashing (see above) in the measurement procedure must be taken into account when comparing predicted and observed ISS. From the stoichiometry of the conversion from metal hydroxide to metal oxide, $1 \mathrm{~g}$ aluminium hydroxide $\left(\mathrm{Al}(\mathrm{OH})_{3}\right)$ contributes $0.66 \mathrm{~g} \mathrm{ISS}$ (i.e. $\mathrm{Al}_{2} \mathrm{O}_{3}$ ) while $1 \mathrm{~g}$ ferric hydroxide $\left(\mathrm{Fe}(\mathrm{OH})_{3}\right)$ contributes $0.75 \mathrm{~g}$ ISS (i.e. $\mathrm{Fe}_{2} \mathrm{O}_{3}$ ). Similarly, based on the generic metal hydroxy-phosphate formula $\left(\mathrm{Me}_{\mathrm{r}} \mathrm{PO}_{4}(\mathrm{OH})_{3 \mathrm{r}-3}\right)$, conversion to a generic metal "phosphateoxide" $\left(\mathrm{Me}_{\mathrm{r}} \mathrm{PO}_{4}(\mathrm{O})_{1.5 \mathrm{r}-1.5}\right)$ can be used to calculate the predicted ISS contribution (De Haas et al., 2000c to d; 2001a).

Figure 5 shows a comparison of observed and predicted DISS values, based on IAWQ model provisions for TSS but applying the 


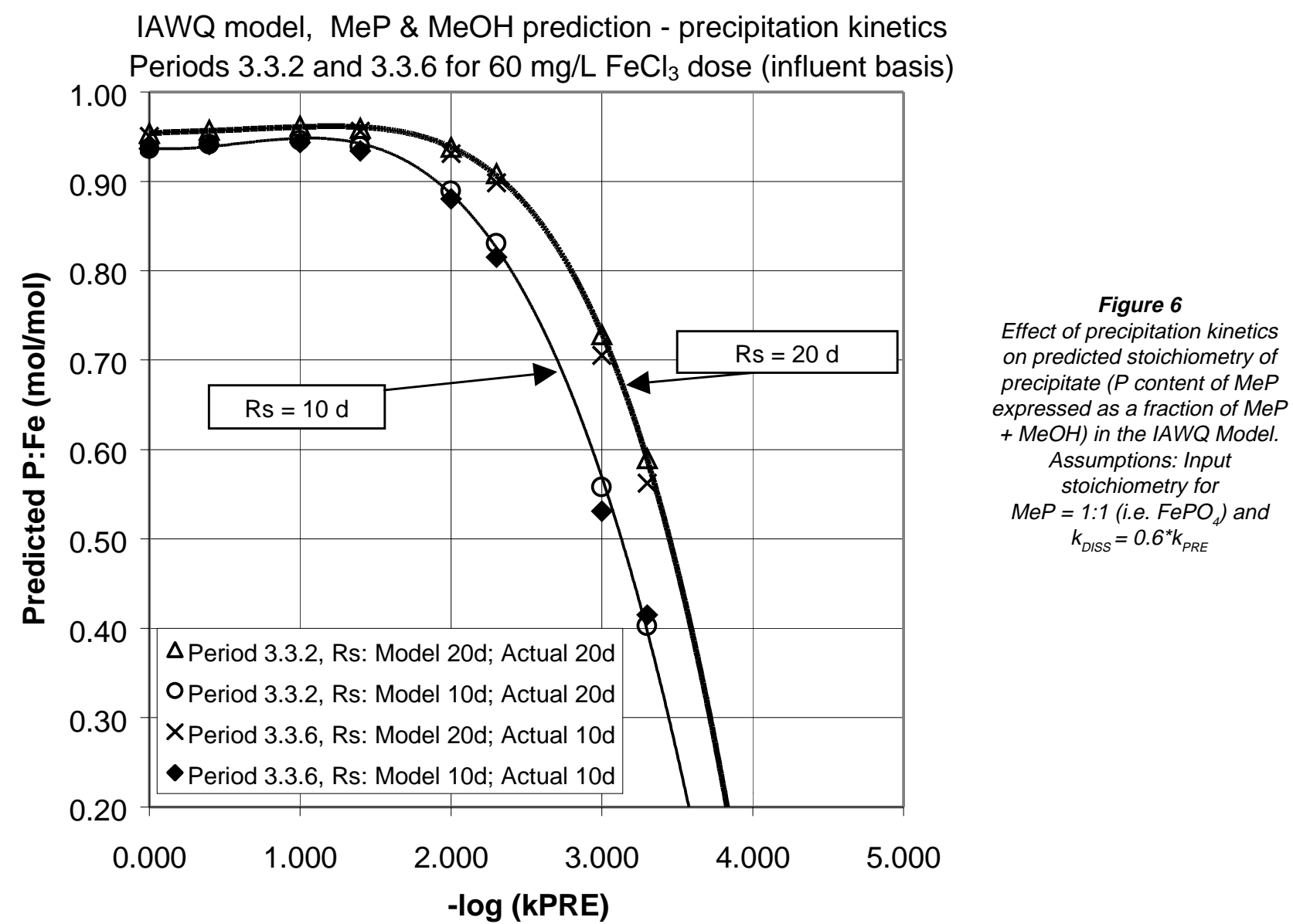

above-mentioned correction factor for model predictions of $\mathrm{MeOH}$ contribution to ISS. In making this correction, the stoichiometry of the metal (hydroxy) phosphate precipitate was taken into account, based on the generalised formula $\mathrm{Me}_{\mathrm{r}} \mathrm{PO}_{4}(\mathrm{OH})_{3 \mathrm{r}-3}$ (refer to De Haas et al., 2000c to d; 2001a).

In most cases, the differences between observed and predicted DISS observed (Fig. 5) were relatively small $(<500 \mathrm{mg} / \ell$, or $<9 \%$ of the mixed liquor TSS in the test unit). Similar results were obtained from calculations based on the observed system P removal and fractionation data (De Haas et al., 2000c to d; 2001a). However, for some periods, close agreement between observed DISS and that predicted by the IAWQ model was not obtained (Fig. 5). This suggests that during these periods the pilot plants did not operate sufficiently closely to "steady-state" in all respects, as borne out by the mass balances (De Haas et al., 2000c to d; 2001a). The largest discrepancies between observed and predicted DISS results could be ascribed to large changes in the mixed liquor solids contents as a result of changes in the metal salt dose rate and/or experimental periods being too short (Fig. 5).

It may be concluded that the provisions in the IAWQ ASM2 model for TSS predictions in the presence of chemical addition are adequate, provided the stoichiometry of phosphate precipitation has been suitably calibrated. Furthermore, in comparing measured ISS with model predictions, metal hydroxide conversion to metal oxide during the ashing procedure needs to be taken into account.

\section{Precipitation kinetics}

The IAWQ ASM2 model (Henze et al., 1995) makes provision for two chemical processes: precipitation and redissolution. That is, there are two kinetic expressions, each with a rate constant, namely
$\mathrm{k}_{\mathrm{PRE}}$ and $\mathrm{k}_{\mathrm{DISS}}$ respectively (De Haas et al., 2001b). The stoichiometry of precipitation is defined as being "ideal" (i.e. $1 \mathrm{~mol} \mathrm{P} / \mathrm{mol}$ $\mathrm{Fe})$. No recommendations are made for application of the model to precipitants other than iron [III] salts (e.g. ferric chloride).

To calibrate the two processes for chemical precipitation in the IAWQ model, either the stoichiometry or the kinetic constants may be adjusted. As a point of departure in this study, the stoichiometric constants were adjusted on the basis that these could be linked directly to the precipitation stoichiometry observed. Henze et al. (1995) provided no guidelines for the choice of the kinetic constants $\mathrm{k}_{\mathrm{PRE}}$ and $\mathrm{k}_{\mathrm{DISS}}$, other than the suggested values of $\mathrm{k}_{\mathrm{PRE}}=1 \mathrm{l} /(\mathrm{mg}$ $\mathrm{FeOH}_{3} . \mathrm{d}$ ) and $\mathrm{k}_{\mathrm{DISS}}=0.6 / \mathrm{d}$ for ferric chloride. Accordingly, these default values were accepted and the stoichiometry adjusted as necessary to match predicted and observed effluent phosphate concentrations in the test unit (see Modelling Method and results discussed above).

Using the suggested default kinetic constants for precipitation/ redissolution, the IAWQ model predicted very low residual (steady state) metal hydroxide $(\mathrm{MeOH})$ concentrations in the mixed liquor ( $<40 \mathrm{mg} / \ell$ for periods without P limitation and $<100 \mathrm{mg} / \ell$ for Plimited periods). Also, the predicted $\mathrm{MeOH}$ concentration showed very little difference for systems operated at $10 \mathrm{~d}$ sludge age, compared with a $20 \mathrm{~d}$ sludge age. This seemed surprising, considering that a lower stoichiometry (or lower apparent precipitation "efficiency") was observed at the shorter sludge age (De Haas, 2000d). The model predictions do need to be seen in the context of the adjusted stoichiometry: For example, under P-limiting conditions, the P:Fe molar ratio (stoichiometry) was adjusted from $1: 1$ to between 0.3 and $0.6: 1$ (Table 4 ). Hence, the implicit formula for the predicted metal phosphate precipitate ranged from $\mathrm{Fe}_{1.67} \mathrm{PO}_{4}(\mathrm{OH})_{2}$ to $\mathrm{Fe}_{3.3} \mathrm{PO}_{4}(\mathrm{OH})_{7}$, which is similar to that modelled 
IAWQ model, Effluent SPO4 prediction - precipitation kinetics

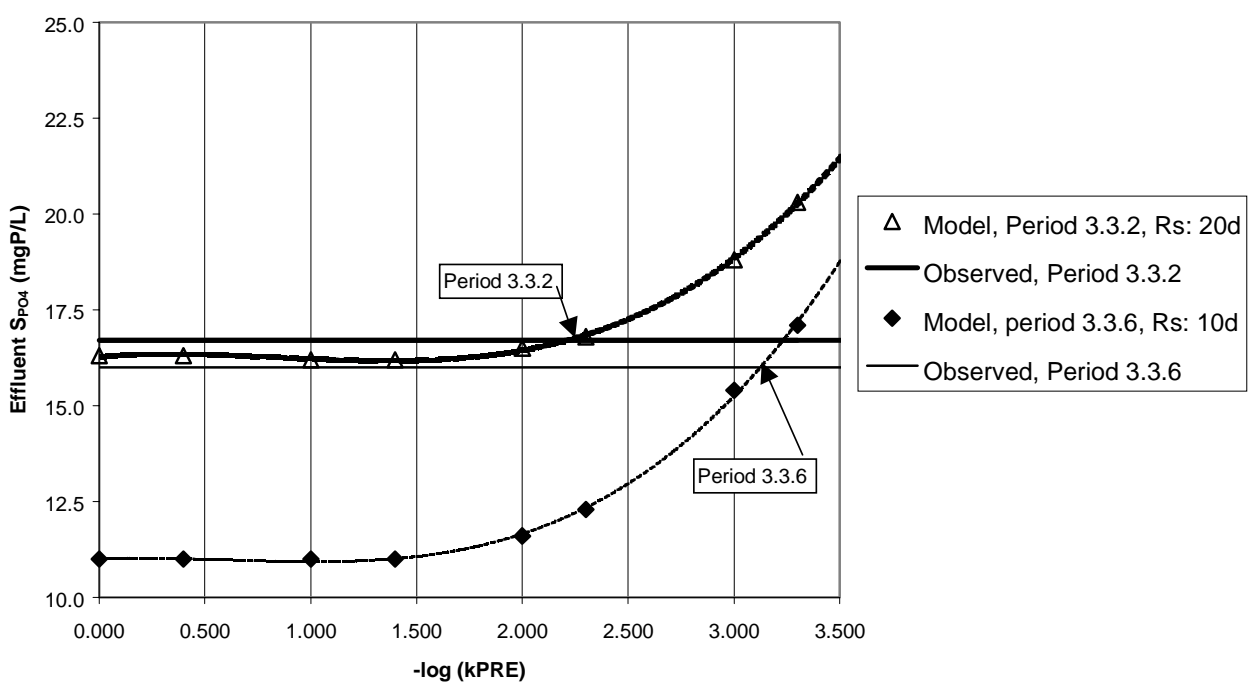

Figure 7

Match between predicted and observed effluent $P$ by manipulation of precipitation kinetics for two experimental periods with ferric chloride dosing at different sludge ages, as modelled in Fig. 8

Figure 8

Match between predicted and observed effluent $P$ by adjustment of precipitation kinetics for all experimental periods in this study. Assumption:

Model input Me:P stoichiometry $=1: 1$ for P-limiting conditions by Luedecke et al. (1989). If the model prediction for metal hydroxy phosphate on this basis is converted back to the ideal precipitates (e.g. $\mathrm{FePO}$ and $\mathrm{Fe}(\mathrm{OH})_{3}$ as in the IAWQ model formulation), then effectively the predicted steadystate amount of metal hydroxide would be greater (e.g. compare predictions in Table 5 for Periods 3.6.1 and 3.6.2a at model input stoichiometry $1.0 \mathrm{vs} 0.75)$. Hence, it is possible to adapt the IAWQ model for precipitates other than $\mathrm{FePO}_{4}$ and $\mathrm{Fe}(\mathrm{OH})_{3}$, including those for aluminium salts, by adjusting the input stoichiometry. However, it would be inelegant and tedious to model the effect of sludge age (solids retention time) by means of adjusting the stoichiometry.

It was not an objective at the outset of this study to examine the effect of sludge age on simultaneous chemical precipitation. However, as outlined in Part 4 (De Haas et al., 2000d), operational constraints with the pilot plants were posed by reactor solids concentration and sludge settling, forcing a change from a $20 \mathrm{~d}$ to a $10 \mathrm{~d}$ sludge age. This was carried out during a period of ferric chloride dosing. From an examination of the difference in system $\mathrm{P}$ removal, this change appeared to result in a reduction in the apparent P:Me stoichiometry of precipitation by about half (De Haas et al., 2000d). This aspect requires further experimental investigation in order to confirm the observations made. Assuming that the observations were correct, then applying the IAWQ model with the default precipitation kinetic constants does not predict a significant change in P:Me ratio in response to sludge age. Figure 6 illustrates the effect of sludge age on predicted P:Me ratio. Also shown is the effect of decreasing $\mathrm{k}_{\mathrm{PRE}}$ from the IAWQ default value of $1 \ell /(\mathrm{mg} \cdot \mathrm{d})$ (i.e. $-\log \mathrm{k}_{\mathrm{PRE}}$ increasing from the default zero on the $\mathrm{x}$-axis), but keeping a constant ratio between $\mathrm{k}_{\mathrm{PRE}}$ and $\mathrm{k}_{\mathrm{DISS}}$ such that $\mathrm{k}_{\mathrm{DISS}}=0.6 * \mathrm{k}_{\mathrm{PRE}}$ (Henze et al., 1995). From Fig. 6 it is clear that over the first one to two log decreases, the predicted P:Me (i.e. P:Fe in this case) stoichiometry shows virtually no change and is relatively insensitive to sludge age. The reason for this is that the reaction rates set by $\mathrm{k}_{\mathrm{PRE}}$ and $\mathrm{k}_{\mathrm{DISS}}$ are high in relation to the solids retention time (i.e. sludge age), allowing the precipitation reaction to be virtually complete; only a small amount of metal hydroxide remains in the system at steady state. To reach a condition where sludge age has a more significant effect on the predicted P:Me stoichiometry, $\mathrm{k}_{\mathrm{PRE}}$ would need to be decreased into the approximate range 0.005 $\left(-\log \mathrm{k}_{\mathrm{PRE}}=2.3\right)$ to $0.0005\left(-\log \mathrm{k}_{\mathrm{PRE}}=3.3\right)$. Figure 6 shows that for Period 3.3.2 (actual sludge age $20 \mathrm{~d}$ ) with $\mathrm{k}_{\mathrm{PRE}}$ set at $0.001\left(-\log \mathrm{k}_{\mathrm{PRE}}\right.$ $=2.7$ ), the model predicts a P:Me ratio of 0.73 for a $20 \mathrm{~d}$ sludge age and 0.56 for a $10 \mathrm{~d}$ sludge age. Observed values from fractionation 
data or P removal data for periods in which a valid comparison may be made were: 0.60 to 1.03 at a $20 \mathrm{~d}$ sludge age and 0.49 to 0.52 at a $10 \mathrm{~d}$ sludge age (refer to Table 4). [Note: This comparison is constrained by mass balance considerations, as well as the impact of BEPR mechanism "inhibition" on $\mathrm{D} P_{\text {trem }}$ calculations and the extent to which complete recovery of "chemical precipitate" fractions occurred in the fractionation procedure - refer to De Haas et al., 2000d and the preceding discussion]. By relating the data in Fig. 6 and Table 4, an analogous argument may be applied to the model predictions for Period 3.3.6 (actual sludge age $10 \mathrm{~d}$ ).

Figure 7 shows that effluent $P$ predictions could be matched to the observed data with $\mathrm{k}_{\mathrm{PRE}}$ values $0.0056\left(-\log \mathrm{k}_{\mathrm{PRE}}=2.25\right)$ and $0.0006\left(-\log \mathrm{k}_{\mathrm{PRE}}=3.2\right)$, for Periods 3.3.2 and 3.3.6 respectively. By iteration, similar values for $\mathrm{k}_{\mathrm{PRE}}$ could be derived for the other experimental periods. Additional experimental data for chemicallydosed systems operated under well-controlled conditions but different sludge ages would be required to derive an appropriate median value for $\mathrm{k}_{\mathrm{PRE}}$. The limits (e.g. range of sludge ages) for validity of a derived constant value for $\mathrm{k}_{\mathrm{PRE}}$ would need to also need to be assessed. As a first attempt, a $\mathrm{k}_{\mathrm{PRE}}$ value of $0.00316\left(-\log \mathrm{k}_{\mathrm{PRE}}\right.$ $=2.5$ from Fig. 7) was adopted for ferric chloride (or ferrous-ferric chloride blend) dosing periods by trial-and-error, and a $\mathrm{k}_{\mathrm{PRE}}$ value of 0.0006 (- $\left.\log \mathrm{k}_{\mathrm{PRE}}=3.22\right)$ was adopted for alum dosing periods. Again assuming $\mathrm{k}_{\mathrm{DISS}}=0.6^{*} \mathrm{k}_{\mathrm{PRE}}$ and constant input $\mathrm{P}: \mathrm{Me}$ stoichiometry at 1:1 (Henze et al., 1995), the results presented in Fig. 8 were derived for all experimental periods modelled in this study. It can be seen that Fig. 8 resembles Fig. 2 with fairly good agreement between predicted and observed effluent $\mathrm{P}$ results. Further refinement could be achieved by manipulation of $\mathrm{k}_{\mathrm{PRE}}$ for individual experimental periods, which would be analogous to manipulation of the input stoichiometry as in Fig. 3. Since the kinetics of the precipitation (or ion exchange reactions) should be independent of sludge age, the validity of such manipulation should be confirmed by experimentation. Particular care is required to ensure steady state in the test systems used as a basis for modelling in such experiments.

\section{Conclusions}

- The IAWQ ASM2 model, which incorporates a simple kinetic model for simultaneous chemical precipitation/dissociation, was tested using the pilot plant experimental results of this study. Calibration against the results for the control unit (not chemically dosed) highlighted the following:

For the control unit (model assumption with BEPR only), agreement between predicted and observed results was satisfactory in most cases, given the variation in influent composition and the influent characterisation procedure adopted. It is important to note that in the modelling approach adopted here, the influent TKN concentration was manipulated where necessary, in order to match predicted and observed effluent nitrate concentrations; in this manner, the impact of recycled nitrate on the BEPR mechanism was minimised.

In order to improve agreement between observed reactor and/or effluent phosphate results and those predicted using the IAWQ model (both in the presence and absence of chemical addition), it was found that the constant defining the relationship between biological P release and PHA formation $\left(\mathrm{Y}_{\mathrm{PO} 4}\right)$ required adjustment in the range 0.50 to $0.57 \mathrm{mgP} / \mathrm{mgCOD}$. Once suitable model calibration had produced satisfactory agreement between observed and predicted $\mathrm{P}$ removal for the control unit, the same model calibration was applied to the test unit receiving metal salt addition.

For ferric chloride, using the kinetic and stoichiometric constants suggested in IAWQ ASM2, the assumption of 1:1 (molar) precipitation stoichiometry for $\mathrm{P}: \mathrm{Fe}$ appeared to be valid for three experimental periods at a $20 \mathrm{~d}$ sludge age. For the remaining periods at a $10 \mathrm{~d}$ sludge age, a lower model input $\mathrm{P}: \mathrm{Fe}$ stoichiometry was required, in the range 0.60 to $0.90 \mathrm{~mol} \mathrm{P} / \mathrm{mol} \mathrm{Fe}$. These results suggest reduced precipitation efficiency at a shorter sludge age, which is consistent with the hypothesis of Rabinowitz and Marais (1980) that part of the chemical Premoval in simultaneously dosed activated sludge systems is due to a slow ion exchange reaction between colloidal metal hydroxide and soluble phosphate. However, sustained ferric chloride dosing (at a dose of 10 to $20 \mathrm{mg} / \ell \mathrm{Fe}$, based on influent) appears to partially inhibit BEPR (De Haas et al., 2000d) and this would also reflect as a lower precipitation efficiency.

For alum and ferrous-ferric dosing, $\mathrm{P}$ precipitation stoichiometry also appeared to be less than 1:1. For alum, the stoichiometry of precipitation was estimated to be 0.60 to $0.75 \mathrm{~mol} \mathrm{P} / \mathrm{mol} \mathrm{Al}$. For ferrous-ferric chloride, the stoichiometry was also estimated to be close to $0.75 \mathrm{~mol} \mathrm{P/}$ mol Fe.

Under P-limiting (i.e. low effluent P) conditions, precipitation efficiency appeared to be lower, with an estimated $\mathrm{P}: \mathrm{Fe}$ stoichiometry of ca. 0.3 to $0.60 \mathrm{~mol} \mathrm{P} / \mathrm{mol} \mathrm{Fe}$. This is in agreement with the model precipitate stoichiometry of $0.4 \mathrm{~mol} \mathrm{P} / \mathrm{mol} \mathrm{Fe}$ accepted by Luedecke et al. (1989) for limiting phosphorus conditions with ferric chloride from batch and continuous tests using activated sludge in a completely aerobic system. However, the model effluent $P$ predictions are not very sensitive to the input $\mathrm{P}: \mathrm{Fe}$ stoichiometry under $\mathrm{P}$ limiting conditions since the biological and chemical mechanisms compete for available $\mathrm{P}$, leaving little $\mathrm{P}$ in the effluent.

- A significant advantage of the kinetic approach to modelling chemical precipitation processes in IAWQ ASM2 is that it integrates readily with processes describing biological carbon, nitrogen and phosphorus removal in activated sludge systems, and offers the potential for incorporation of processes for $\mathrm{pH}$ and alkalinity. A kinetic-based model for mixed, three-phase [solid/liquid/gas], weak acid-base systems using the AQUASIM model platform has been proposed by Musvuto et al. (1997). This could form a further extension to the IAWQ ASM2 model applied here. In this extension, precipitation efficiency in relation to alkalinity (and/or $\mathrm{pH}$ ) in simultaneous precipitation processes would need further investigation. This study found circumstantial evidence (De Haas et al., 2000c) suggesting that reactor $\mathrm{pH}$ (and hence system alkalinity) plays a role in determining the extent of inhibition of the biological P removal mechanism in the presence of simultaneous metal salt addition, particularly with alum. Furthermore, the question of alkalinity consumption in relation to the $\mathrm{Me}: \mathrm{P}$ stoichiometry of precipitation has not been adequately addressed in the IAWQ model.

- Satisfactory agreement between (IAWQ model) predicted and observed values for polyP in the control system was obtained when comparing the model predictions with observed values from sludge $P$ fractionation. For the test system (metal dosed) the differences between the predicted and observed polyP data 
tended to be larger in some experimental periods, particularly those at relatively high metal doses or sustained periods at lower metal dose. Partial inhibition of the BEPR mechanism had apparently occurred in these periods (De Haas et al., 2000c \&d; 2001a) in a manner which the IAWQ ASM2 model is not able to predict. However, better agreement between the fractionation data and IAWQ model polyP predictions were obtained for relatively long experimental periods with ferric chloride dosing under conditions of phosphate limitation. This implies that the model formulation is correct in so far as the principal interaction between the chemical and biological mechanisms appears to be competition for available phosphate. Most real applications of the model will be for conditions that are basically P-limited, due to the need to achieve the lowest possible effluent $\mathrm{P}$ concentrations.

- Broad agreement (usually to within $\pm 9 \%$ of reactor TSS in the test unit) was found between IAWQ model predictions and observed increases in inorganic suspended solids (ISS) due to chemical addition, provided the necessary stoichiometric adjustments were made for metal hydroxy phosphate precipitation and for conversion of metal hydroxide to metal oxide during ashing. Where differences were found between model predictions and observed ISS, these could be generally accounted for on the basis of inconsistencies in the experimental solids data, which were not at steady-state in all cases.

- Using available data, a brief investigation was carried out into the kinetics of precipitation/redissolution processes in the IAWQ ASM2 model. This investigation suggested that the default value for the rate constant for precipitation $\left(\mathrm{k}_{\mathrm{PRE}}\right)$ should be decreased from $1 \ell /(\mathrm{mgMeOH} \cdot \mathrm{d})$ to between 0.0006 (for alum) and 0.003 (for ferric and/or ferrous chloride). The relationship $\mathrm{k}_{\mathrm{DISS}}=0.6^{*} \mathrm{k}_{\mathrm{PRE}}$ in ASM2 appeared to be acceptable.

- It is possible to obtain equivalent predictions for $\mathrm{P}$ removal using the IAWQ ASM2 model by adjusting either the stoichiometry or kinetics of the precipitation/ redissolution processes. To the extent that the kinetics should be independent of sludge age but capable of predicting differences in observed precipitation stoichiometry at different sludge ages, adjustment of the kinetics would seem the preferred option. However, since the kinetic constants for these processes are apparent and cannot be measured directly, further research into the calibration of these kinetic parameters is required to improve confidence in model predictions for systems at different sludge ages. Moreover, the relationship between the precipitation/ redissolution kinetics and reactor $\mathrm{pH} /$ alkalinity as well as the possibility of co-precipitation of calcium and/or magnesium ions will need to be investigated in order to confidently incorporate simultaneous precipitation into a combined model for the physical, chemical and biological processes of activated sludge systems (Musvuto, 1998). The advantage of such a combined model is the capability for prediction of processes governed by chemical equilibria, including $\mathrm{pH}$, alkalinity and ion-pairing effects, which affect soluble metal ion and phosphate residuals.

\section{References}

DE HAAS DW (1998) The Use of Simultaneous Chemical Precipitation in Modified Activated Sludge Systems Exhibiting Biological Enhanced Phosphate Removal. PhD Thesis, Dept. of Civil Eng., Univ. of Cape Town, Rondebosch, Cape Town, South Africa.
DE HAAS DW, WENTZEL MC and EKAMA GA (2000a) The use of simultaneous mical precipitation in modified activated sludge systems exhibiting biological enhanced phosphate removal. Part 1: Literature review. Water SA 26 (4) 439-452.

DE HAAS DW, WENTZEL MC and EKAMA GA (2000b) The use of simultaneous chemical precipitation in modified activated sludge systems exhibiting biological enhanced phosphate removal. Part 2: Method development for fractionation of phosphate compounds in activated sludge. Water SA 26 (4) 453-466.

DE HAAS DW, WENTZEL MC and EKAMA GA (2000c) The use of simultaneous chemical precipitation in modified activated sludge systems exhibiting biological enhanced phosphate removal. Part 3: Experimental periods using alum. Water SA 26 (4) 467-484.

DE HAAS DW, WENTZEL MC and EKAMA GA (2000d) The use of simultaneous chemical precipitation in modified activated sludge systems exhibiting biological enhanced phosphate removal. Part 4: Experimental periods using ferric chloride. Water SA 26 (4) 485-504.

DE HAAS DW, WENTZEL MC and EKAMA GA (2001a) The use of simultaneous chemical precipitation in modified activated sludge systems exhibiting biological enhanced phosphate removal. Part 5: Experimental periods using a ferrous-ferric chloride blend. Water SA 27 (2) 117-134.

DE HAAS DW, WENTZEL MC and EKAMA GA (2001b) The use of simultaneous chemical precipitation in modified activated sludge systems exhibiting biological enhanced phosphate removal. Part 6: Modelling of simultaneous chemical-biological Premoval-Review of existing models. Water SA 27 (2) 135-150.

HENZE M, GUJER W, MINO T, MATSUO T, WENTZEL MC and MARAIS GvR (1995) Activated Sludge Model No. 2. IAWQ Task Group on Math. Modelling for Design and Operation of Biol. Nutrient Wastewater Treatment Processes. Int. Assoc. on Water Quality, 1 Queen Anne's Gate, London.

LUEDECKE C, HERMANOWICZ SH and JENKINS D (1989) Precipitation of ferric phosphate in activated sludge: a chemical model and its verification. Water Sci. Technol. 21 (Brighton) 325-327.

MAMAIS D, JENKINS D and PITT P (1993) A rapid-physico-chemical method for the determination of readily biodegradable soluble COD in municipal wastewater. Water Res. 27 (1) 195-197.

MUSVUTO EV, WENTZEL MC, LOEWENTHAL RE and MARAIS GvR (1997) Kinetic based model for mixed acid/base systems. Water SA 23 (4) 311-322.

MUSVUTO EV (1998) Mathematical Modelling of Integrated Chemical, Physical and Biological Treatment of Wastewaters. PhD thesis, Dept. of Civil Eng., Univ. of Cape Town, Rondebosch, Cape Town, South Africa.

RABINOWITZ B and MARAIS GvR (1980) Chemical and Biological Phosphorus Removal in the Activated Sludge Process. Research Report No. W32, Univ. of Cape Town, Dept. of Civil Eng.

REICHERT P (1994) Concepts Underlying a Computer Program for the Identification and Simulation of Aquatic Systems. Swiss Fed. Inst. for Environ. Sci. and Technol. (EAWAG), Dübendorf, Switzerland.

SMOLDERS GJF, VAN DER MEIJM J, VAN LOOSDRECHT MCM and HEIJNEN JJ (1994) Model of the anaerobic metabolism of the biological phosphorus removal process; stoichiometry and $\mathrm{pH}$ influence. Biotechnol. and Bioeng. 43 461-470.

STANDARD METHODS (1985) Standard Methods for the Examination of Water and Wastewater (16th edn.) American Public Health Association, Washington DC.

WENTZEL MC (1997) Personal communication. Dept. of Civil Eng., Univ. of Cape Town, South Africa.

WENTZEL MC and EKAMA GA (1995) Modelling of biological nutrient removal activated sludge systems - An overview. Paper presented at Bio-P Hannover 95 Int. Conf., Hannover, Germany.

WENTZEL MC, EKAMA GA and MARAIS GvR (1992) Processes and modelling of nitrification denitrification biological excess phosphorus removal systems - A review. Water Sci. Technol. 25 (6) 59-82.

WENTZEL MC, EKAMA GA, DOLD PL and MARAIS GvR (1990) Biological excess phosphorus removal - Steady state process design. Water SA 16 (1), 29 -48.

WRC (1984) Theory, Design and Operation of Nutrient Removal Activated Sludge Processes. Water Research Commission, PO Box 824, Pretoria, South Africa. 
TABLE A1

Results for key variables, comparing IAWQ model predictions with observed data for control unit (R2)

\begin{tabular}{|c|c|c|c|c|c|c|c|c|c|c|c|c|c|c|c|c|c|c|}
\hline \multirow[t]{4}{*}{ Period } & \multicolumn{4}{|c|}{ Effluent phosphate } & \multicolumn{4}{|c|}{ Effluent nitrate } & \multicolumn{2}{|c|}{$\begin{array}{c}\text { Effluent } \\
\text { ammonia }\end{array}$} & \multicolumn{2}{|c|}{$\begin{array}{l}\text { Effluent } \\
\text { TKN }\end{array}$} & \multicolumn{2}{|c|}{$\begin{array}{l}\text { Reactor } \\
\text { OUR (AE2) }\end{array}$} & \multicolumn{2}{|c|}{$\begin{array}{l}\text { Reactor } \\
\text { VSS (AE2) }\end{array}$} & \multirow{3}{*}{$\begin{array}{c}\text { VSS } \\
\text { Obs/ } \\
\text { Model }\end{array}$} & \multirow{3}{*}{$\begin{array}{r}\text { COD } \\
\text { Bal. }\end{array}$} \\
\hline & Model & Obs. & Obs. & \multirow{2}{*}{$\begin{array}{c}\text { Diff } \\
\text { based } \\
\text { on } S_{\mathrm{TP}}\end{array}$} & Model & Obs. & Obs. & & Model & Obs. & Model & Obs. & Model & Obs. & Model & Obs. & & \\
\hline & $\mathrm{S}_{\mathrm{PO} 4}$ & $S_{T P}$ & $\mathrm{~S}_{\mathrm{PO4}}$ & & $\mathrm{S}_{\mathrm{NO} 3}$ & $\mathrm{~S}_{\mathrm{NO} 3}$ & $\mathrm{~S}_{\mathrm{NO} 3(\mathrm{AE} 2)}$ & on Ave & $\mathrm{S}_{\mathrm{NH} 4}$ & $\mathrm{~S}_{\mathrm{NH} 4}$ & $\mathrm{~S}_{\mathrm{TKN}}$ & $C_{T K N}$ & OURt & OURt & $\mathbf{x}_{\mathrm{vss}}$ & $\mathbf{x}_{\mathrm{vss}}$ & & \\
\hline & $\mathrm{mgP} / \mathrm{l}$ & $\mathrm{mgP} / \ell$ & $\mathrm{mgP} / \ell$ & $\mathrm{mgP} / \ell$ & $\mathrm{mgN} / \ell$ & $\mathrm{mgN} / \ell$ & $\mathrm{mgN} / \ell$ & $\mathrm{mgN} / \ell$ & $\mathrm{mgN} / \ell$ & $\mathrm{mgN} / \ell$ & $\mathrm{mgN} / \ell$ & $\mathrm{mgN} / \ell$ & $\mathrm{mg} /(\ell \cdot h)$ & $\mathbf{m g} /(\ell \cdot \mathbf{h})$ & $\mathrm{mg} / \ell$ & $\mathrm{mg} / \ell$ & $\%$ & $\%$ \\
\hline $\begin{array}{c}3.2 .2 \\
3.2 .3 \\
3.2 .4 \\
3.2 .5 \\
3.2 .7 \\
3.2 .8 \mathrm{a}\end{array}$ & $\begin{array}{l}28.4 \\
25.5 \\
24.6 \\
29.2 \\
28.1 \\
26.4\end{array}$ & $\begin{array}{l}28.9 \\
25.3 \\
23.7 \\
29.7 \\
28.3 \\
26.8\end{array}$ & $\begin{array}{l}27.6 \\
23.1 \\
22.5 \\
29.2 \\
31.8 \\
25.8\end{array}$ & $\begin{array}{c}-0.5 \\
0.2 \\
0.9 \\
-0.5 \\
-0.2 \\
-0.4\end{array}$ & $\begin{array}{l}2.6 \\
5.9 \\
3.9 \\
6.0 \\
4.5 \\
3.5\end{array}$ & $\begin{array}{l}2.4 \\
5.8 \\
3.3 \\
6.0 \\
4.3 \\
3.6\end{array}$ & $\begin{array}{l}2.4 \\
6.0 \\
2.7 \\
6.1 \\
4.8 \\
3.1\end{array}$ & $\begin{array}{l}0.2 \\
0.0 \\
0.9 \\
0.0 \\
0.0 \\
0.2\end{array}$ & $\begin{array}{l}0.2 \\
0.4 \\
0.7 \\
0.4 \\
0.1 \\
0.3\end{array}$ & $\begin{array}{c}0.3 \\
0.4 \\
0.7 \\
0.4 \\
<0.1 \\
0.3\end{array}$ & $\begin{array}{l}2.8 \\
3.2 \\
2.1 \\
2.2 \\
2.0 \\
2.4\end{array}$ & $\begin{array}{l}2.9 \\
3.7 \\
2.4 \\
1.9 \\
2.0 \\
2.3\end{array}$ & $\begin{array}{l}18.6 \\
15.9 \\
14.1 \\
10.8 \\
14.1 \\
12.9\end{array}$ & $\begin{array}{l}20.9 \\
16.6 \\
15.4 \\
12.1 \\
11.4 \\
11.1\end{array}$ & $\begin{array}{l}2610 \\
2336 \\
2203 \\
1528 \\
2039 \\
1940\end{array}$ & $\begin{array}{l}2693 \\
2749 \\
2386 \\
1911 \\
1894 \\
1885\end{array}$ & $\begin{array}{c}103 \% \\
118 \% \\
108 \% \\
125 \% \\
93 \% \\
97 \%\end{array}$ & $\begin{array}{l}112 \% \\
109 \% \\
111 \% \\
122 \% \\
87 \% \\
90 \%\end{array}$ \\
\hline $\begin{array}{l}3.3 .1 \mathrm{~b} \\
3.3 .2 \\
3.3 .3 \\
3.3 .4 \\
3.3 .5 \\
3.3 .6\end{array}$ & $\begin{array}{l}28.9 \\
26.9 \\
28.5 \\
21.3 \\
25.9 \\
21.2\end{array}$ & $\begin{array}{l}27.7 \\
27.0 \\
28.3 \\
21.2 \\
25.3 \\
21.6\end{array}$ & $\begin{array}{l}26.0 \\
27.2 \\
27.9 \\
20.8 \\
25.0 \\
21.8\end{array}$ & $\begin{array}{c}1.2 \\
-0.1 \\
0.2 \\
0.1 \\
0.6 \\
-0.4\end{array}$ & $\begin{array}{l}\mathbf{6 . 4} \\
\mathbf{5 . 0} \\
\mathbf{5 . 9} \\
\mathbf{5 . 7} \\
\mathbf{6 . 6} \\
\mathbf{6 . 0}\end{array}$ & $\begin{array}{l}6.3 \\
5.5 \\
6.3 \\
6.0 \\
6.6 \\
6.1\end{array}$ & $\begin{array}{l}6.1 \\
4.4 \\
6.9 \\
6.0 \\
7.4 \\
5.9\end{array}$ & $\begin{array}{c}0.2 \\
0.0 \\
-0.7 \\
-0.3 \\
-0.4 \\
0.0\end{array}$ & $\begin{array}{l}0.1 \\
0.9 \\
0.9 \\
1.3 \\
1.3 \\
0.7\end{array}$ & $\begin{array}{l}0.2 \\
1.2 \\
1.2 \\
1.7 \\
1.7 \\
0.6\end{array}$ & $\begin{array}{l}2.5 \\
2.5 \\
2.9 \\
2.7 \\
3.5 \\
2.3\end{array}$ & $\begin{array}{l}2.3 \\
2.6 \\
2.6 \\
3.2 \\
2.8 \\
2.5\end{array}$ & $\begin{array}{l}18.4 \\
17.8 \\
21.2 \\
16.3 \\
15.3 \\
13.3\end{array}$ & $\begin{array}{l}16.2 \\
18.2 \\
15.5 \\
13.9 \\
12.8 \\
14.7\end{array}$ & $\begin{array}{l}2286 \\
2460 \\
2526 \\
1805 \\
1464 \\
1320\end{array}$ & $\begin{array}{l}2490 \\
2509 \\
2424 \\
1987 \\
1546 \\
1319\end{array}$ & $\begin{array}{c}109 \% \\
102 \% \\
96 \% \\
110 \% \\
106 \% \\
100 \%\end{array}$ & $\begin{array}{l}114 \% \\
102 \% \\
95 \% \\
98 \% \\
92 \% \\
98 \%\end{array}$ \\
\hline $\begin{array}{l}3.4 .1 \\
3.4 .2 \\
3.4 .3 \\
3.4 .4\end{array}$ & $\begin{array}{c}25.7 \\
26.8 \\
31.0 \\
2.3\end{array}$ & $\begin{array}{c}25.8 \\
27.2 \\
31.2 \\
2.1\end{array}$ & $\begin{array}{c}23.1 \\
25.6 \\
29.6 \\
2.1\end{array}$ & $\begin{array}{c}-0.1 \\
-0.4 \\
-0.2 \\
0.2\end{array}$ & $\begin{array}{l}2.8 \\
4.4 \\
3.7 \\
6.7\end{array}$ & $\begin{array}{l}2.8 \\
4.0 \\
3.9 \\
6.6\end{array}$ & $\begin{array}{l}2.7 \\
4.4 \\
3.6 \\
6.5\end{array}$ & $\begin{array}{c}0.0 \\
0.2 \\
-0.1 \\
0.2\end{array}$ & $\begin{array}{l}1.0 \\
1.0 \\
0.6 \\
0.4\end{array}$ & $\begin{array}{l}1.1 \\
1.3 \\
0.6 \\
0.2\end{array}$ & $\begin{array}{l}1.9 \\
1.8 \\
2.6 \\
2.5\end{array}$ & $\begin{array}{l}2.1 \\
2.2 \\
2.8 \\
2.3\end{array}$ & $\begin{array}{c}7.6 \\
11.4 \\
10.4 \\
13.0\end{array}$ & $\begin{array}{c}8.5 \\
10.6 \\
10.7 \\
11.6\end{array}$ & $\begin{array}{c}913 \\
903 \\
835 \\
1014\end{array}$ & $\begin{array}{l}1135 \\
892 \\
781 \\
945\end{array}$ & $\begin{array}{c}124 \% \\
99 \% \\
94 \% \\
93 \%\end{array}$ & $\begin{array}{c}98 \% \\
97 \% \\
99 \% \\
110 \%\end{array}$ \\
\hline $\begin{array}{l}3.5 .1 \\
3.5 .2\end{array}$ & $\begin{array}{l}6.1 \\
3.4\end{array}$ & $\begin{array}{l}6.1 \\
3.7\end{array}$ & $\begin{array}{l}5.2 \\
2.3\end{array}$ & $\begin{array}{c}0.0 \\
-0.3\end{array}$ & $\begin{array}{c}10.4 \\
8.7\end{array}$ & $\begin{array}{l}9.9 \\
8.6\end{array}$ & $\begin{array}{l}10.6 \\
8.3\end{array}$ & $\begin{array}{l}0.2 \\
0.2\end{array}$ & $\begin{array}{l}0.4 \\
0.4\end{array}$ & $\begin{array}{l}0.3 \\
0.2\end{array}$ & $\begin{array}{l}2.3 \\
3.6\end{array}$ & $\begin{array}{l}2.3 \\
3.4\end{array}$ & $\begin{array}{l}11.3 \\
14.6\end{array}$ & $\begin{array}{l}11.9 \\
13.1\end{array}$ & $\begin{array}{l}875 \\
957\end{array}$ & $\begin{array}{l}965 \\
985\end{array}$ & $\begin{array}{l}110 \% \\
103 \%\end{array}$ & $\begin{array}{l}101 \% \\
108 \%\end{array}$ \\
\hline $\begin{array}{c}3.6 .1 \\
3.6 .2 \mathrm{a}\end{array}$ & $\begin{array}{l}0.16 \\
0.09\end{array}$ & $\begin{array}{l}0.43 \\
0.62\end{array}$ & $\begin{array}{l}0.21 \\
0.44\end{array}$ & $\begin{array}{l}-0.3 \\
-0.5\end{array}$ & $\begin{array}{l}6.7 \\
4.9\end{array}$ & $\begin{array}{l}6.2 \\
4.7\end{array}$ & $\begin{array}{l}6.7 \\
4.7\end{array}$ & $\begin{array}{l}0.3 \\
0.1\end{array}$ & $\begin{array}{l}0.5 \\
0.5\end{array}$ & $\begin{array}{l}0.5 \\
0.6\end{array}$ & $\begin{array}{l}2.2 \\
2.2\end{array}$ & $\begin{array}{l}2.2 \\
2.1\end{array}$ & $\begin{array}{l}13.4 \\
14.7\end{array}$ & $\begin{array}{l}14.2 \\
12.9\end{array}$ & $\begin{array}{l}1225 \\
1205\end{array}$ & $\begin{array}{l}1218 \\
1186\end{array}$ & $\begin{array}{l}99 \% \\
98 \%\end{array}$ & $\begin{array}{c}99 \% \\
100 \%\end{array}$ \\
\hline \multicolumn{19}{|c|}{ Excluding Periods with P limitation (Periods 3.4.4, 3.5.1, 3.5.2, 3.6.1 \& 3.6.2a) } \\
\hline $\begin{array}{c}\text { Mean } \\
\text { SD }\end{array}$ & $\begin{array}{c}26.6 \\
2.7\end{array}$ & $\begin{array}{c}26.5 \\
2.8\end{array}$ & $\begin{array}{l}25.8 \\
3.1\end{array}$ & $\begin{array}{l}0.0 \\
0.5\end{array}$ & $\begin{array}{l}4.9 \\
1.3\end{array}$ & $\begin{array}{l}4.9 \\
1.4\end{array}$ & $\begin{array}{l}4.8 \\
1.6\end{array}$ & $\begin{array}{l}\text { 0.0 } \\
0.4\end{array}$ & $\begin{array}{l}0.7 \\
0.4\end{array}$ & $\begin{array}{l}0.8 \\
0.5\end{array}$ & $\begin{array}{l}2.5 \\
0.5\end{array}$ & $\begin{array}{l}2.6 \\
0.5\end{array}$ & $\begin{array}{c}14.5 \\
3.6\end{array}$ & $\begin{array}{l}13.9 \\
3.3\end{array}$ & $\begin{array}{c}1811 \\
616\end{array}$ & $\begin{array}{l}1907 \\
649\end{array}$ & $\begin{array}{l}106 \% \\
10 \%\end{array}$ & $\begin{array}{l}102 \% \\
10 \%\end{array}$ \\
\hline \multicolumn{19}{|c|}{ Periods with P limitation (Periods 3.4.4, 3.5.1, 3.5.2, 3.6.1 \& 3.6.2a) } \\
\hline $\begin{array}{c}\text { Mean } \\
\text { SD }\end{array}$ & $\begin{array}{l}2.4 \\
2.5\end{array}$ & $\begin{array}{l}2.6 \\
2.3\end{array}$ & $\begin{array}{l}2.0 \\
2.0\end{array}$ & $\begin{array}{l}-0.2 \\
0.2\end{array}$ & $\begin{array}{l}7.5 \\
2.1\end{array}$ & $\begin{array}{l}7.2 \\
2.0\end{array}$ & $\begin{array}{l}7.3 \\
2.2\end{array}$ & $\begin{array}{c}0.2 \\
0.04\end{array}$ & $\begin{array}{l}0.4 \\
0.1\end{array}$ & $\begin{array}{l}0.4 \\
0.2\end{array}$ & $\begin{array}{l}2.6 \\
0.6\end{array}$ & $\begin{array}{l}2.5 \\
0.5\end{array}$ & $\begin{array}{c}13.4 \\
1.4\end{array}$ & $\begin{array}{c}12.7 \\
1.0\end{array}$ & $\begin{array}{c}1055 \\
154\end{array}$ & $\begin{array}{c}1060 \\
131\end{array}$ & $\begin{array}{c}101 \% \\
6 \%\end{array}$ & $\begin{array}{c}104 \% \\
5 \%\end{array}$ \\
\hline
\end{tabular}




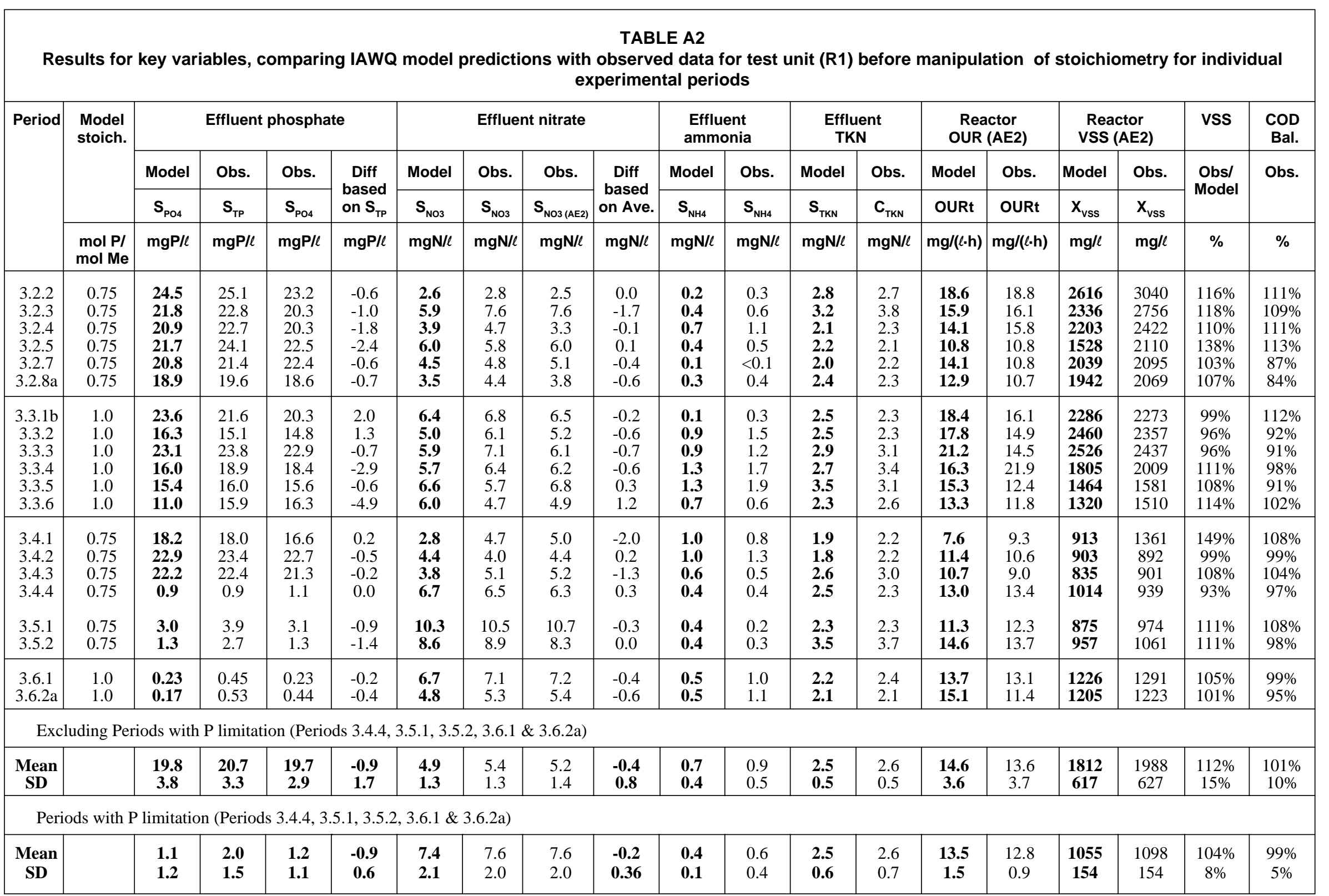




\begin{tabular}{|c|c|c|c|c|c|c|c|c|c|c|c|c|c|c|c|c|c|c|c|}
\hline \multicolumn{20}{|c|}{$\begin{array}{c}\text { TABLE A3 } \\
\text { Results for key variables, comparing IAWQ model predictions with observed data for test Reactor (R1) after manipulation of stoichiometry for individual } \\
\text { experimental periods }\end{array}$} \\
\hline \multirow[t]{4}{*}{ Period } & \multirow{4}{*}{$\begin{array}{l}\begin{array}{c}\text { Model } \\
\text { stoich. }\end{array} \\
\\
\mathrm{mol} \mathrm{P/} \\
\mathrm{mol} \mathrm{Me}\end{array}$} & \multicolumn{4}{|c|}{ Effluent phosphate } & \multicolumn{4}{|c|}{ Effluent nitrate } & \multicolumn{2}{|c|}{$\begin{array}{c}\text { Effluent } \\
\text { ammonia }\end{array}$} & \multicolumn{2}{|c|}{$\begin{array}{l}\text { Effluent } \\
\text { TKN }\end{array}$} & \multicolumn{2}{|c|}{$\begin{array}{c}\text { Reactor } \\
\text { OUR (AE2) }\end{array}$} & \multicolumn{2}{|c|}{$\begin{array}{l}\text { Reactor } \\
\text { VSS (AE2) }\end{array}$} & \multirow{3}{*}{$\begin{array}{c}\text { VSS } \\
\text { Obs/ } \\
\text { Model }\end{array}$} & \multirow{3}{*}{$\begin{array}{r}\text { COD } \\
\text { Bal. } \\
\text { Obs. }\end{array}$} \\
\hline & & Model & Obs. & Obs. & \multirow{2}{*}{$\begin{array}{c}\text { Diff } \\
\text { based } \\
\text { on } S_{T P}\end{array}$} & Model & Obs. & Obs. & \multirow{2}{*}{$\begin{array}{c}\text { Diff } \\
\text { based } \\
\text { on Ave. }\end{array}$} & Model & Obs. & Model & Obs. & Model & Obs. & Model & Obs. & & \\
\hline & & $\mathrm{S}_{\mathrm{PO4}}$ & $S_{T P}$ & $\mathrm{~S}_{\mathrm{PO} 4}$ & & $\mathrm{~S}_{\mathrm{NO3}}$ & $\mathrm{S}_{\mathrm{NO} 3}$ & $\mathrm{~S}_{\mathrm{NO} 3(\mathrm{AE2})}$ & & $\mathrm{S}_{\mathrm{NH} 4}$ & $\mathrm{~S}_{\mathrm{NH} 4}$ & $\mathbf{S}_{\mathrm{TKN}}$ & $\mathrm{C}_{\mathrm{TKN}}$ & OURt & OURt & $\mathbf{x}_{\mathrm{vss}}$ & $\mathbf{x}_{\mathrm{vss}}$ & & \\
\hline & & $\mathrm{mgP} / \ell$ & $\mathrm{mgP} / \ell$ & $\mathrm{mgP} / \ell$ & $\mathrm{mgP} / \ell$ & $\mathrm{mgN} / \ell$ & $\mathrm{mgN} / \ell$ & $\mathrm{mgN} / \ell$ & $\mathrm{mgN} / \ell$ & $\mathrm{mgN} / \ell$ & $\mathrm{mgN} / \ell$ & $\mathrm{mgN} / \ell$ & $\mathrm{mgN} / \ell$ & $\mathrm{mg} /(l \cdot h)$ & $\mathrm{mg} /(l \cdot h)$ & $\mathrm{mg} / \ell$ & $\mathrm{mg} / \ell$ & $\%$ & $\%$ \\
\hline $\begin{array}{c}3.2 .2 \\
\mathbf{3 . 2 . 3} \\
\mathbf{3 . 2 . 4} \\
\mathbf{3 . 2 . 5} \\
3.2 .7 \\
3.2 .8 \mathrm{a}\end{array}$ & $\begin{array}{c}0.75 \\
\mathbf{0 . 6} \\
\mathbf{0 . 6} \\
\mathbf{0 . 6} \\
0.75 \\
0.75\end{array}$ & $\begin{array}{l}24.5 \\
22.5 \\
21.6 \\
23.1 \\
20.8 \\
18.9\end{array}$ & $\begin{array}{l}25.1 \\
22.8 \\
22.7 \\
24.1 \\
21.4 \\
19.6\end{array}$ & $\begin{array}{l}23.2 \\
20.3 \\
20.3 \\
22.5 \\
22.4 \\
18.6\end{array}$ & $\begin{array}{l}-0.6 \\
-0.3 \\
-1.1 \\
-1.0 \\
-0.6 \\
-0.7\end{array}$ & $\begin{array}{l}2.6 \\
5.9 \\
3.9 \\
6.0 \\
5.3 \\
3.5\end{array}$ & $\begin{array}{l}2.8 \\
7.6 \\
4.7 \\
5.8 \\
4.8 \\
4.4\end{array}$ & $\begin{array}{l}2.5 \\
7.6 \\
3.3 \\
6.0 \\
5.1 \\
3.8\end{array}$ & $\begin{array}{c}0.0 \\
-1.7 \\
-0.1 \\
0.1 \\
0.4 \\
-0.6\end{array}$ & $\begin{array}{l}0.2 \\
0.4 \\
0.7 \\
0.4 \\
0.1 \\
0.3\end{array}$ & $\begin{array}{c}0.3 \\
0.6 \\
1.1 \\
0.5 \\
<0.1 \\
0.4 \\
\end{array}$ & $\begin{array}{l}2.8 \\
3.2 \\
2.1 \\
2.2 \\
2.0 \\
2.4\end{array}$ & $\begin{array}{l}2.7 \\
3.8 \\
2.3 \\
2.1 \\
2.2 \\
2.3\end{array}$ & $\begin{array}{l}19.5 \\
16.0 \\
14.1 \\
10.8 \\
14.1 \\
12.9\end{array}$ & $\begin{array}{l}18.8 \\
16.1 \\
15.8 \\
10.8 \\
10.8 \\
10.7\end{array}$ & $\begin{array}{l}2392 \\
2336 \\
2203 \\
1528 \\
2039 \\
1942\end{array}$ & $\begin{array}{l}3040 \\
2756 \\
2422 \\
2110 \\
2095 \\
2069\end{array}$ & $\begin{array}{l}127 \% \\
118 \% \\
110 \% \\
138 \% \\
103 \% \\
107 \%\end{array}$ & $\begin{array}{l}111 \% \\
109 \% \\
111 \% \\
113 \% \\
87 \% \\
84 \%\end{array}$ \\
\hline $\begin{array}{c}3.3 .1 \mathrm{~b} \\
3.3 .2 \\
3.3 .3 \\
\text { 3.3.4 } \\
\text { 3.3.5 } \\
\text { 3.3.6 }\end{array}$ & $\begin{array}{l}1.0 \\
1.0 \\
1.0 \\
\mathbf{0 . 6 0} \\
\mathbf{0 . 9 0} \\
\mathbf{0 . 6 0}\end{array}$ & $\begin{array}{l}23.6 \\
16.3 \\
23.1 \\
18.1 \\
16.4 \\
15.0\end{array}$ & $\begin{array}{l}21.6 \\
15.1 \\
23.8 \\
18.9 \\
16.0 \\
15.9\end{array}$ & $\begin{array}{l}20.3 \\
14.8 \\
22.9 \\
18.4 \\
15.6 \\
16.3\end{array}$ & $\begin{array}{c}2.0 \\
1.3 \\
-0.7 \\
-0.8 \\
0.4 \\
-0.9\end{array}$ & $\begin{array}{l}6.4 \\
5.0 \\
5.9 \\
5.7 \\
6.6 \\
\mathbf{6 . 0}\end{array}$ & $\begin{array}{l}6.8 \\
6.1 \\
7.1 \\
6.4 \\
5.7 \\
4.7\end{array}$ & $\begin{array}{l}6.5 \\
5.2 \\
6.1 \\
6.2 \\
6.8 \\
4.9\end{array}$ & $\begin{array}{c}-0.2 \\
-0.6 \\
-0.7 \\
-0.6 \\
0.3 \\
1.2\end{array}$ & $\begin{array}{l}0.1 \\
0.9 \\
0.9 \\
1.3 \\
1.3 \\
0.7\end{array}$ & $\begin{array}{l}0.3 \\
1.5 \\
1.2 \\
1.7 \\
1.9 \\
0.6\end{array}$ & $\begin{array}{l}2.5 \\
2.5 \\
2.9 \\
2.7 \\
3.5 \\
2.3\end{array}$ & $\begin{array}{l}2.3 \\
2.3 \\
3.1 \\
3.4 \\
3.1 \\
2.6\end{array}$ & $\begin{array}{l}18.4 \\
17.8 \\
21.2 \\
16.3 \\
15.3 \\
13.3\end{array}$ & $\begin{array}{l}16.1 \\
14.9 \\
14.5 \\
21.9 \\
12.4 \\
11.8\end{array}$ & $\begin{array}{l}2286 \\
2460 \\
2526 \\
1805 \\
1464 \\
1320\end{array}$ & $\begin{array}{l}2273 \\
2357 \\
2437 \\
2009 \\
1581 \\
1510\end{array}$ & $\begin{array}{c}99 \% \\
96 \% \\
96 \% \\
111 \% \\
108 \% \\
114 \%\end{array}$ & $\begin{array}{c}112 \% \\
92 \% \\
91 \% \\
98 \% \\
91 \% \\
102 \%\end{array}$ \\
\hline $\begin{array}{l}3.4 .1 \\
3.4 .2 \\
3.4 .3 \\
\mathbf{3 . 4 . 4}\end{array}$ & $\begin{array}{l}0.75 \\
0.75 \\
0.75 \\
\mathbf{0 . 4 0}\end{array}$ & $\begin{array}{c}18.2 \\
22.9 \\
22.2 \\
1.3\end{array}$ & $\begin{array}{c}18.0 \\
23.4 \\
22.4 \\
0.9\end{array}$ & $\begin{array}{c}16.6 \\
22.7 \\
21.3 \\
1.1\end{array}$ & $\begin{array}{c}0.2 \\
-0.5 \\
-0.2 \\
0.4\end{array}$ & $\begin{array}{l}2.8 \\
4.4 \\
3.8 \\
6.7\end{array}$ & $\begin{array}{l}4.7 \\
4.0 \\
5.1 \\
6.5\end{array}$ & $\begin{array}{l}5.0 \\
4.4 \\
5.2 \\
6.3\end{array}$ & $\begin{array}{c}-2.0 \\
0.2 \\
-1.3 \\
0.3\end{array}$ & $\begin{array}{l}1.0 \\
1.0 \\
0.6 \\
0.4\end{array}$ & $\begin{array}{l}0.8 \\
1.3 \\
0.5 \\
0.4\end{array}$ & $\begin{array}{l}1.9 \\
1.8 \\
2.6 \\
2.5\end{array}$ & $\begin{array}{l}2.2 \\
2.2 \\
3.0 \\
2.3\end{array}$ & $\begin{array}{c}7.6 \\
11.4 \\
10.7 \\
13.0\end{array}$ & $\begin{array}{c}9.3 \\
10.6 \\
9.0 \\
13.4\end{array}$ & $\begin{array}{c}913 \\
903 \\
835 \\
1014\end{array}$ & $\begin{array}{l}1361 \\
892 \\
901 \\
939\end{array}$ & $\begin{array}{c}149 \% \\
99 \% \\
108 \% \\
93 \%\end{array}$ & $\begin{array}{c}108 \% \\
99 \% \\
104 \% \\
97 \%\end{array}$ \\
\hline $\begin{array}{l}3.5 .1 \\
3.5 .2\end{array}$ & $\begin{array}{l}0.40 \\
0.40\end{array}$ & $\begin{array}{l}4.2 \\
1.9\end{array}$ & $\begin{array}{l}3.9 \\
2.7\end{array}$ & $\begin{array}{l}3.1 \\
1.3\end{array}$ & $\begin{array}{c}0.3 \\
-0.8\end{array}$ & $\begin{array}{c}10.3 \\
8.6\end{array}$ & $\begin{array}{l}10.5 \\
8.9\end{array}$ & $\begin{array}{l}10.7 \\
8.3\end{array}$ & $\begin{array}{c}-0.3 \\
0.0\end{array}$ & $\begin{array}{l}0.4 \\
0.4\end{array}$ & $\begin{array}{l}0.2 \\
0.3\end{array}$ & $\begin{array}{l}2.3 \\
3.5\end{array}$ & $\begin{array}{l}2.3 \\
3.7\end{array}$ & $\begin{array}{l}11.3 \\
14.6\end{array}$ & $\begin{array}{l}12.3 \\
13.7\end{array}$ & $\begin{array}{l}875 \\
957\end{array}$ & $\begin{array}{c}974 \\
1061\end{array}$ & $\begin{array}{l}111 \% \\
111 \%\end{array}$ & $\begin{array}{l}108 \% \\
98 \%\end{array}$ \\
\hline $\begin{array}{c}3.6 .1 \\
\text { 3.6.2a }\end{array}$ & $\begin{array}{l}0.60 \\
0.60\end{array}$ & $\begin{array}{l}0.15 \\
0.10\end{array}$ & $\begin{array}{l}0.45 \\
0.53\end{array}$ & $\begin{array}{l}0.23 \\
0.44\end{array}$ & $\begin{array}{l}-0.3 \\
-0.4\end{array}$ & $\begin{array}{l}6.7 \\
4.8\end{array}$ & $\begin{array}{l}7.1 \\
5.3\end{array}$ & $\begin{array}{l}7.2 \\
5.4\end{array}$ & $\begin{array}{l}-0.4 \\
-0.6\end{array}$ & $\begin{array}{l}0.5 \\
0.5\end{array}$ & $\begin{array}{l}1.0 \\
1.1\end{array}$ & $\begin{array}{l}2.2 \\
2.1\end{array}$ & $\begin{array}{l}2.4 \\
2.1\end{array}$ & $\begin{array}{l}13.7 \\
15.1\end{array}$ & $\begin{array}{l}13.1 \\
11.4\end{array}$ & $\begin{array}{l}1226 \\
1205\end{array}$ & $\begin{array}{l}1291 \\
1223\end{array}$ & $\begin{array}{l}105 \% \\
101 \%\end{array}$ & $\begin{array}{l}99 \% \\
95 \%\end{array}$ \\
\hline Excl & uding Per & ods with & P limita & on (Peric & is 3.4.4, & $5.1,3.5$ & 3.6 .1 & 3.6.2a) & & & & & & & & & & & \\
\hline $\begin{array}{l}\text { Mean } \\
\text { SD }\end{array}$ & & $\begin{array}{c}18.1 \\
7.3\end{array}$ & $\begin{array}{l}18.3 \\
7.4\end{array}$ & $\begin{array}{l}17.5 \\
7.0\end{array}$ & $\begin{array}{c}-0.3 \\
0.8\end{array}$ & $\begin{array}{l}5.0 \\
1.3\end{array}$ & $\begin{array}{l}5.5 \\
1.3\end{array}$ & $\begin{array}{l}5.4 \\
1.4\end{array}$ & $\begin{array}{c}-0.4 \\
0.8\end{array}$ & $\begin{array}{l}0.6 \\
0.4\end{array}$ & $\begin{array}{l}0.9 \\
0.5\end{array}$ & $\begin{array}{l}2.5 \\
0.5\end{array}$ & $\begin{array}{l}2.6 \\
0.5\end{array}$ & $\begin{array}{l}14.6 \\
3.5\end{array}$ & $\begin{array}{l}13.4 \\
3.5\end{array}$ & $\begin{array}{l}1728 \\
592\end{array}$ & $\begin{array}{c}1902 \\
635\end{array}$ & $\begin{array}{c}111 \% \\
15 \%\end{array}$ & $\begin{array}{c}100 \% \\
9 \%\end{array}$ \\
\hline Peric & ds with $\mathrm{F}$ & mitatic & Perio & $.4 .4,3$ &, 3.5 & $6.1 \&$ & $6.2 a)$ & & & & & & & & & & & & \\
\hline $\begin{array}{c}\text { Mean } \\
\text { SD }\end{array}$ & & $\begin{array}{l}1.5 \\
1.7\end{array}$ & $\begin{array}{l}2.0 \\
1.5\end{array}$ & $\begin{array}{l}1.2 \\
1.1\end{array}$ & $\begin{array}{c}-0.4 \\
0.5\end{array}$ & $\begin{array}{l}7.4 \\
2.1\end{array}$ & $\begin{array}{l}7.6 \\
2.0\end{array}$ & $\begin{array}{l}7.6 \\
2.0\end{array}$ & $\begin{array}{l}-0.2 \\
0.36\end{array}$ & $\begin{array}{l}0.4 \\
0.1\end{array}$ & $\begin{array}{l}0.6 \\
0.4\end{array}$ & $\begin{array}{l}2.5 \\
0.6\end{array}$ & $\begin{array}{l}2.6 \\
0.7\end{array}$ & $\begin{array}{c}13.5 \\
1.5\end{array}$ & $\begin{array}{c}12.8 \\
0.9\end{array}$ & $\begin{array}{l}1055 \\
154\end{array}$ & $\begin{array}{c}1098 \\
154\end{array}$ & $\begin{array}{c}104 \% \\
8 \%\end{array}$ & $\begin{array}{c}99 \% \\
5 \%\end{array}$ \\
\hline
\end{tabular}

